\title{
Fast identification and quantification of uropathogenic $E$. coli through cluster analysis
}

Jean-Baptiste Vendevillet, Mathew John Kyriakides ${ }^{\dagger}$, Yuiko Takebayashi ${ }^{\sharp}$, Sylvain Ramat, James Preece ${ }^{\dagger}$, Jenny Samphire ${ }^{\ddagger}$, Javier Ramos-Soriano ${ }^{+}$, Abraham Mauleon Amieva ${ }^{\dagger}$, Maisie Emma Holbrow-Wilshaw ${ }^{\dagger}$, Henry Ralph Gordon Newman ${ }^{\dagger}$, Sio Lou Kou*, Sandra MedinaVillar $^{\dagger}$, Neciah Dorh ${ }^{\dagger}$, Josephine Ndoa Dorh ${ }^{\dagger^{*}}$, James Spencer ${ }^{\# *}$, M. Carmen Galan ${ }^{t^{*}}$

†FluoretiQ, Unit DX, St Philips Central, Albert Road, Bristol, BS2 0XJ, United Kingdom;

${ }^{\ddagger}$ School of Chemistry, Cantock's Close, BS8 1TS, Bristol, United Kingdom

\#School of Cellular and Molecular Medicine, University of Bristol, University Walk, BS8 1TD, Bristol, United Kingdom

*Corresponding authors: josephine.dorh@fluoretiq.com, Jim.Spencer@bristol.ac.uk, M.C.Galan@bristol.ac.uk

\section{Experimental section}

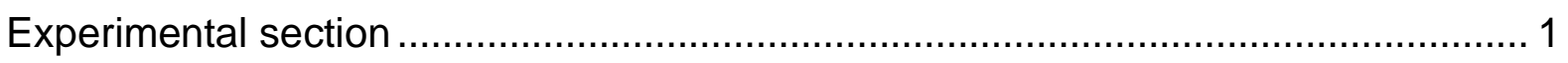

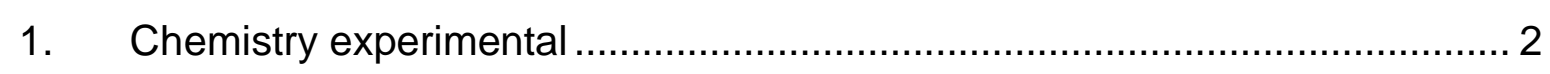

1,2,3,4,6-Penta-O-acetyl-D-mannopyranose S2 .......................................... 2

2,3,4,6-Tetra-O-acetyl-D-mannopyranose S3 .............................................. 3

2,3,4,6-tetra-O-acetyl-a-D-mannopyranosyl trichloroacetimidate S4 .................. 3

3'-chloropropyl-2,3,4,6-O-acetyl-a-D-mannopyranoside S5 ............................ 4

3'-Azidopropyl-2,3,4,6-O-acetyl-D-mannopyranoside S6 ................................. 4

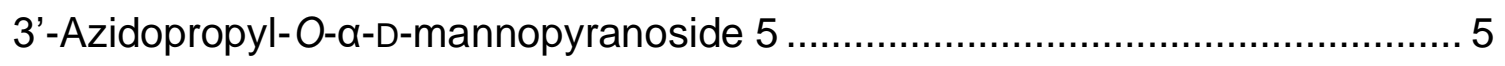

7'-Bromoheptyl-2,3,4,6-O-acetyl- $\alpha$-D-mannopyranoside S7 ............................ 5

7'-Azidoheptyl-2,3,4,6-O-acetyl- $\alpha$-D-mannopyranoside S8.............................. 6

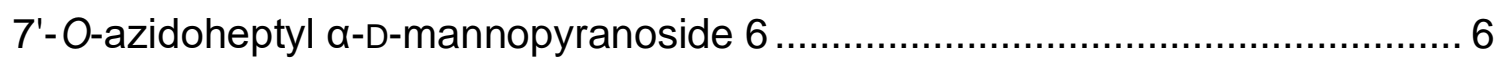

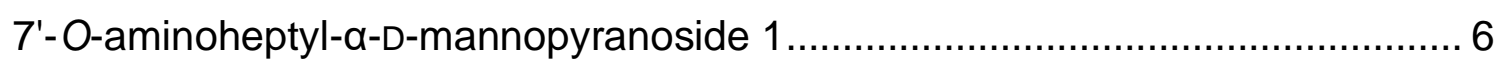

10'-Bromodecyl-2,3,4,6-O-acetyl-D-mannopyranoside S8 .............................. 7

10'-azidodecyl-2,3,4,6-O-acetyl-D-mannopyranoside S9 ............................... 7

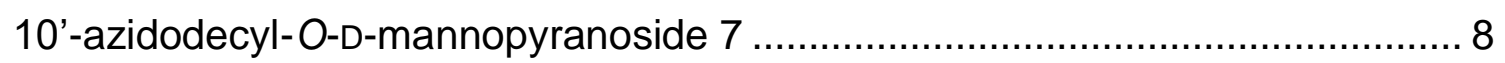

Determination of glycan coated microspheres using CuAAC ........................... 8 
First step: CuAAC reaction of non-fluorescent coumarin and propargyl amine in presence and absence of microspheres.

Second step: CuAAC reaction between propargylated beads with azidocoumarin.

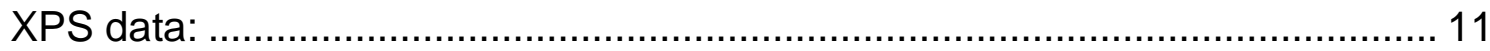

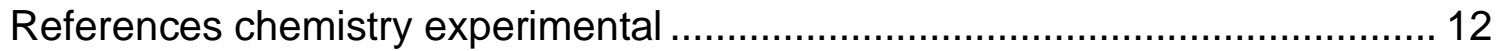

2. Image analysis experimental ................................................................ 13

1 Morphological reconstruction algorithm (Old method) ................................... 13

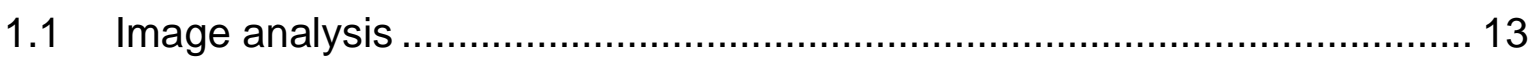

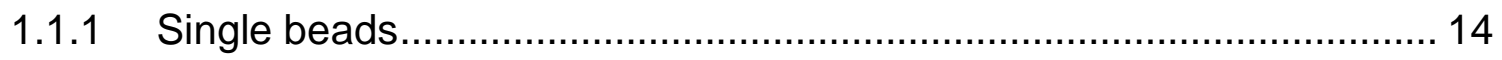

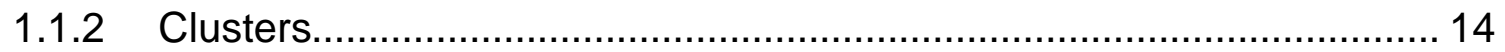

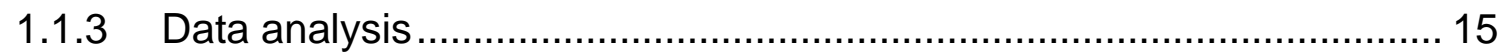

2 Particle tracking algorithm (New method) ………...................................... 15

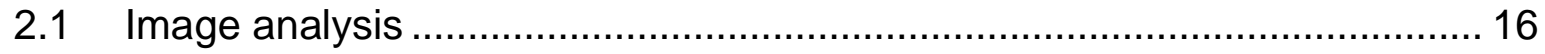

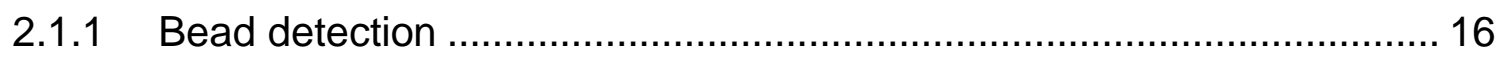

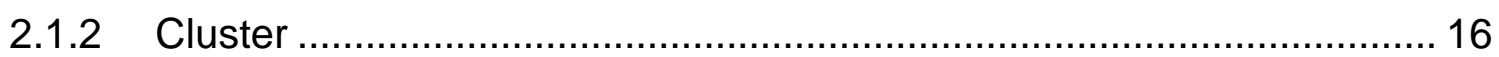

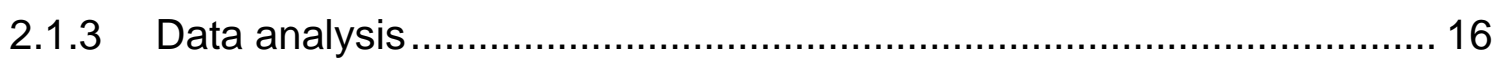

Data generated from the assay..................................................................... 17

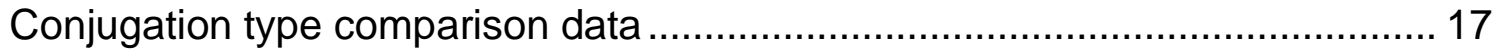

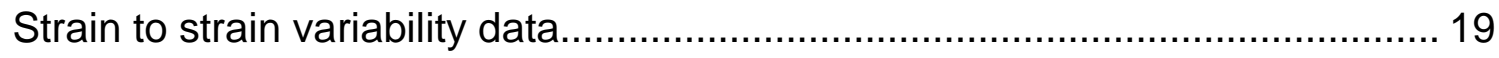

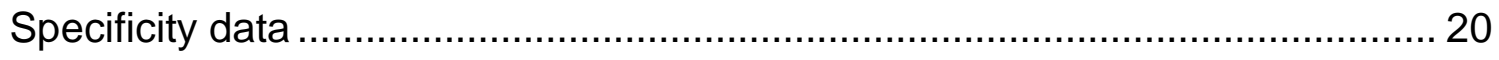

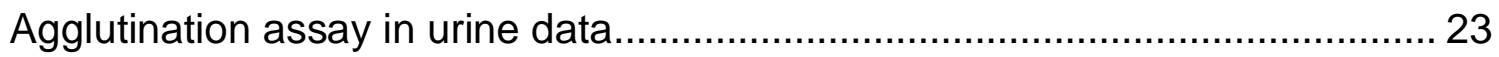

Optimisation by sample concentration data .................................................. 29

\section{Chemistry experimental}

Chemical reagents were obtained from commercial sources (Merck, FisherScientific Itd, Fluorochem Itd, Carbosynth) and used without further purification, unless stated otherwise. All air/moisture sensitive reactions were carried out under inert atmosphere $\left(\mathrm{N}_{2}\right)$ in dried glassware. Anhydrous bottles of THF (tetrahydrofuran), toluene, $\mathrm{CH}_{2} \mathrm{Cl}_{2}$, DMF and $\mathrm{NEt}_{3}$, bought from commercial sources, were used for the reactions. When appropriate, other reagents and solvents were purified by standard techniques. Reactions were monitored by TLC (MERCK Kieselgel $60 \mathrm{~F}_{254}$, aluminium sheet), visualised under UV light (254 nm), and by staining with $\mathrm{KMnO} 4(10 \%$ aq.), sugar dip (5\% W/W $\mathrm{H}_{2} \mathrm{SO}_{4}, \quad 0.3 \% \quad \mathrm{~W} / \mathrm{W} \quad \mathrm{N}$-(1-Naphthyl)ethylenediamine dihydrochloride) or with ninhydrin (1.5\% W/W in $\mathrm{EtOH})$ for compounds bearing an amino functionality. ${ }^{1} \mathrm{H},{ }^{13} \mathrm{C}$, spectra were recorded in $\mathrm{CDCl}_{3}$, acetone- $\mathrm{d}_{6}$, methanol-d 4 or $\mathrm{D}_{2} \mathrm{O}$ using a JEOL400YH (400 and $101 \mathrm{MHz}$ respectively) spectrometer. ${ }^{1} \mathrm{H}$ and ${ }^{13} \mathrm{C}$ chemical shifts $(\delta)$ are quoted in ppm relative to residual solvent peaks as appropriate. The coupling constants $(J)$ were recorded in Hertz $(\mathrm{Hz})$. The coupling constants have not been averaged. HRMS was obtained from a Bruker APEX III FTICR-MS. 


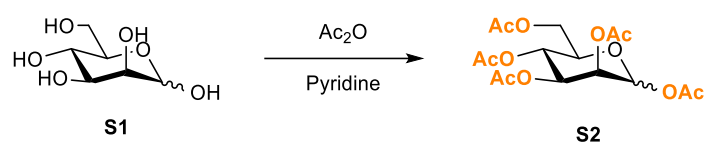

To a solution of $\alpha$-D-Mannose $\mathbf{S} 1(20 \mathrm{~g}, 0.11 \mathrm{~mol})$ in pyridine $(200 \mathrm{~mL})$ was added acetic anhydride $(200 \mathrm{~mL})$. The reaction was stirred for $3 \mathrm{~h}$ at $\mathrm{RT}$ under an atmosphere of $\mathrm{N}_{2}$. The RM was diluted with $\mathrm{CH}_{2} \mathrm{Cl}_{2}(200 \mathrm{~mL})$ then concentrated in vacuo. The crude product was diluted with $\mathrm{CH}_{2} \mathrm{Cl}_{2}(400 \mathrm{~mL})$ and washed with $\mathrm{NaHCO}_{3(\mathrm{aq})}$ sat. (2 $\times 200 \mathrm{~mL})$ followed by $2 \mathrm{M} \mathrm{HCl}(2 \times 200 \mathrm{~mL})$ followed by water $(200 \mathrm{~mL})$. The organic layer was dried with $\mathrm{MgSO}_{4}$, filtered and concentrated in vacuo to afford 1,2,3,4,6penta-O-acetyl-D-mannopyranose $\mathbf{S} 2$ as a thick yellow oil in quantitative yield (42 g, $0.11 \mathrm{mmol}, 100 \%)$. Data are in accordance with the literature. ${ }^{[1,2,3]}$

${ }^{1} \mathrm{H}$ NMR $\left(400 \mathrm{MHz}, \mathrm{CDCl}_{3}\right): \delta 5.83(1 \mathrm{H}, \mathrm{d}, J 1.8 \mathrm{~Hz}), 5.71(1 \mathrm{H}, \mathrm{s}), 5.24(1 \mathrm{H}, \mathrm{d}, J 2.2$ $\mathrm{Hz})$, 5.10-5.09 (2H, m), 5.03-4.99 (2H, m), 4.08-4.01 (2H, m) 3.90-3.83 (3H, m), 3.68$3.64(1 \mathrm{H}, \mathrm{m}), 1.96(3 \mathrm{H}, \mathrm{s}), 1.94(3 \mathrm{H}, \mathrm{s}), 1.86(3 \mathrm{H}, \mathrm{s}), 1.84(3 \mathrm{H}, \mathrm{s}), 1.82(3 \mathrm{H}, \mathrm{s}), 1.76$ $(3 \mathrm{H}, \mathrm{s}), 1.75(3 \mathrm{H}, \mathrm{s}) \mathrm{ppm} ;{ }^{13} \mathrm{C}$ NMR (101 MHz, $\left.\mathrm{CDCl}_{3}\right): \delta$ 170.3, 170.3, 169.9, 169.6, 169.5, 169.4, 169.3, 168.2, 168.1, 167.8, 90.3, 90.1, 72.8, 70.3, 70.3, 68.8, 65.2, 68.5, $68.0,65.2,61.9,61.8,20.5,20.5,20.4,20.4,20.4,20.4,20.4,20.3,20.3,20.2$ ppm;

\section{2,3,4,6-Tetra-O-acetyl-D-mannopyranose S3}

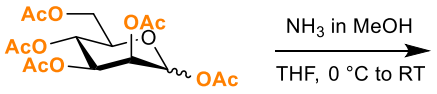

S2

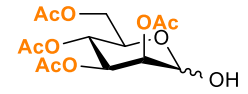

s3

To a solution of 1,2,3,4,6-penta-O-acetyl-D-mannopyranose $\mathbf{S 2}(10 \mathrm{~g}, 25.6 \mathrm{mmol})$ in THF (300 mL) at $0{ }^{\circ} \mathrm{C}$ was added a solution of $\mathrm{NH}_{3}$ in $\mathrm{MeOH}(7 \mathrm{~N}, 73 \mathrm{~mL}, 0.50 \mathrm{~mol})$. The RM was allowed to reach RT and stirred under an $\mathrm{N}_{2}$ atmosphere for $5 \mathrm{~h}$. The reaction was concentrated in vacuo and then purified by column chromatography (silica, $30-50 \%$ acetone in cyclohexane) to give 2,3,4,6-tetra-O-acetyl-Dmannopyranose S3 (6 g, $17 \mathrm{mmol}, 67 \%)$. as a clear oil. Data are in accordance with the literature. ${ }^{[4]}$

${ }^{1} \mathrm{H}$ NMR $\left(400 \mathrm{MHz}, \mathrm{CDCl}_{3}\right): \delta 5.41(1 \mathrm{H}, \mathrm{dd}, J 10.1,3.3 \mathrm{~Hz}), 5.31(1 \mathrm{H}, \mathrm{d}, J 10.3 \mathrm{~Hz})$, $5.26(1 \mathrm{H}, \mathrm{dd}, J 3.4,1.9 \mathrm{~Hz}), 5.24(1 \mathrm{H}, \mathrm{s}), 4.28-4.20(2 \mathrm{H}, \mathrm{m}), 4.17-4.09(1 \mathrm{H}, \mathrm{m})$, $3.60(1 \mathrm{H}, \mathrm{d}, \mathrm{J} 4.2 \mathrm{~Hz}), 2.16(3 \mathrm{H}, \mathrm{s}), 2.10(3 \mathrm{H}, \mathrm{s}), 2.04(3 \mathrm{H}, \mathrm{s}), 2.00(3 \mathrm{H}, \mathrm{s}) \mathrm{ppm} ;{ }^{13} \mathrm{C}$ NMR (101 MHz, $\left.\mathrm{CDCl}_{3}\right): \delta 171.0,170.4,170.2,167.0,92.3,70.1,68.9,68.6,66.3$, $62.7,21.0,20.9(2 \mathrm{C}) \mathrm{ppm}$.

\section{2,3,4,6-tetra-O-acetyl-a-D-mannopyranosyl trichloroacetimidate S4}

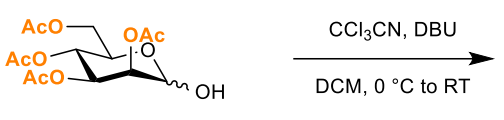

s3

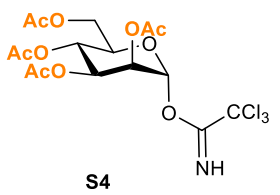

S4

To a solution of 2,3,4,6-tetra-O-acetyl-D-mannopyranose $\mathbf{S} 3(3.0 \mathrm{~g}, 8.6 \mathrm{mmol})$ in dry $\mathrm{CH}_{2} \mathrm{Cl}_{2}(30 \mathrm{~mL})$ at $0{ }^{\circ} \mathrm{C}$ under $\mathrm{N}_{2}, \mathrm{CCl}_{3} \mathrm{CN}(8.9 \mathrm{~mL}, 86 \mathrm{mmol})$ and DBU $(0.25 \mathrm{~mL}, 1.72$ $\mathrm{mmol}$ ) were added. The reaction was allowed to reach RT then stirred for $2 \mathrm{~h}$ before being concentrated in vacuo. Purification by column chromatography (silica, $20-40 \%$ 
acetone in cyclohexane) to give the desired trichloroacetimidate $\mathbf{S 4}(3.30 \mathrm{~g}, 6.7 \mathrm{mmol}$, $78 \%)$ as a yellow oil. Data are in accordance with the literature. ${ }^{[4]}$

${ }^{1} \mathrm{H}$ NMR (400 MHz, CDCl 3$): \delta 8.78(1 \mathrm{H}, \mathrm{NH}, \mathrm{s}), 6.28(1 \mathrm{H}, \mathrm{d}, J 1.9 \mathrm{~Hz}), 5.47(1 \mathrm{H}, \mathrm{m})$, $5.43-5.36(2 \mathrm{H}, \mathrm{m}), 4.28(1 \mathrm{H}, \mathrm{dd}, J 12.0,4.7 \mathrm{~Hz}), 4.22-4.13(2 \mathrm{H}, \mathrm{m}), 2.20(3 \mathrm{H}, \mathrm{s})$, $2.08(3 \mathrm{H}, \mathrm{s}), 2.07(3 \mathrm{H}, \mathrm{s}), 2.01(3 \mathrm{H}, \mathrm{s})$ ppm; ${ }^{13} \mathbf{C}$ NMR (101 $\left.\mathbf{M H z}, \mathbf{C D C l}_{3}\right): \delta$ 170.7, 167.0, 169.9, 169.8, 159.9, 94.7, 90.6, 71.3, 68.9, 68.0, 65.5, 62.2, 20.9, 20.84, 20.82, 20.75 ppm.

\section{3'-chloropropyl-2,3,4,6-O-acetyl-a-D-mannopyranoside S5}

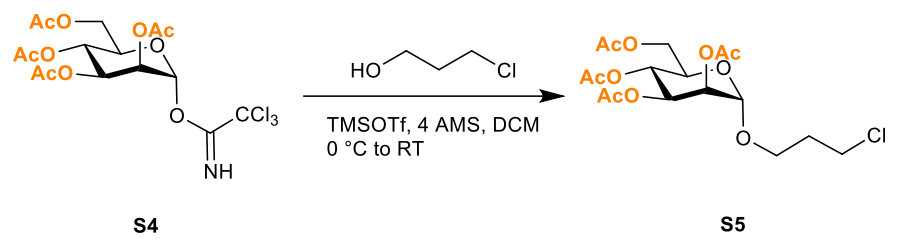

To a solution of trichloroacetimidate $\mathbf{S 4}(1 \mathrm{~g}, 2.0 \mathrm{mmol})$ and pre-activated $4 \AA$ molecular sieves $(2 \mathrm{~g})$ in dry $\mathrm{CH}_{2} \mathrm{Cl}_{2}(15 \mathrm{~mL})$ under $\mathrm{N}_{2}$ was added chloropropanol $(0.25 \mathrm{~mL}, 3.0$ $\mathrm{mmol})$. The RM was stirred for 30 minutes then the reaction was cooled to $0{ }^{\circ} \mathrm{C}$ and TMSOTf $(0.07 \mathrm{~mL}, 0.4 \mathrm{mmol})$ was added dropwise. After $3 \mathrm{~h}$ the reaction was quenched with $\mathrm{NEt}_{3}$ and diluted with $\mathrm{CH}_{2} \mathrm{Cl}_{2}(10 \mathrm{~mL})$, filtered over celite, concentrated in vacuo and purified by column chromatography (silica, 5-15\% acetone in cyclohexane) to give 3'-chloropropyl-2,3,4,6-O-acetyl-D-mannopyranoside S5 (300 $\mathrm{mg}, 0.71 \mathrm{mmol}, 35 \%$ ) as a white solid. Data are in accordance with the literature. ${ }^{[5]}$

${ }^{1} \mathrm{H}$ NMR (400 MHz, CDCl 3$): \delta 5.33-5.22(3 \mathrm{H}, \mathrm{m}), 4.82(1 \mathrm{H}, \mathrm{d}, J 1.6 \mathrm{~Hz}), 4.27(1 \mathrm{H}$, dd, J 12.2, $5.4 \mathrm{~Hz}), 4.12$ (1H, dd, J 12.2, $2.3 \mathrm{~Hz}), 3.99$ (1H, ddd, J 8.0, 5.4, $2.3 \mathrm{~Hz}$ ), $3.91(1 \mathrm{H}$, ddd, J 9.8, 7.3, $5.0 \mathrm{~Hz}), 3.72-3.54(3 \mathrm{H}, \mathrm{m}), 2.15(3 \mathrm{H}, \mathrm{s}), 2.10(3 \mathrm{H}, \mathrm{s}), 2.14$ $-2.00(2 \mathrm{H}, \mathrm{m}), 2.04(3 \mathrm{H}, \mathrm{s}), 1.99(3 \mathrm{H}, \mathrm{s}) \mathrm{ppm}$.

\section{3'-Azidopropyl-2,3,4,6-O-acetyl-D-mannopyranoside S6}

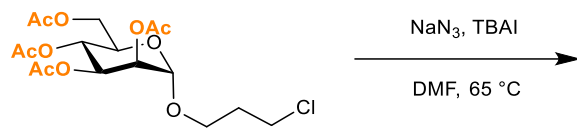

S5

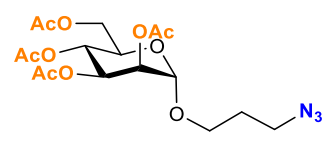

s6

To a solution 3'-chloropropyl-2,3,4,6-O-acetyl-a-D-mannopyranoside S5 (280 mg, 0.66 $\mathrm{mmol})$ in dry DMF (5 mL) was added $\mathrm{NaN}_{3}(214 \mathrm{mg}, 3.2 \mathrm{mmol})$ and TBAI (24 mg, 0.07 $\mathrm{mmol}$ ), the reaction was then heated at $65^{\circ} \mathrm{C}$. After $15 \mathrm{~h}$ the $\mathrm{RM}$ was concentrated in vacuo then diluted with $\mathrm{Et}_{2} \mathrm{O}(15 \mathrm{~mL})$ and washed with $\mathrm{NaHCO}_{3}$ (aq.) sat. $(20 \mathrm{~mL})$. The aqueous layer was extracted with $\mathrm{Et}_{2} \mathrm{O}(15 \mathrm{~mL})$, the combined organic extracts were washed with brine $(2 \times 10 \mathrm{~mL})$, dried with $\mathrm{MgSO}_{4}$, filtered, concentrated in vacuo and then purified by column chromatography (silica, $5-15 \%$ acetone in cyclohexane) to give 3-azidopropyl-2,3,4,6-O-acetyl-a-D-mannopyranoside S6 (188 mg, 0.44 mmol, $66 \%)$ as an off-white solid. Data are in accordance with the literature. ${ }^{[6]}$

${ }^{1} \mathrm{H}$ NMR (400 MHz, CDCl $)$ : $\delta 5.32(1 \mathrm{H}$, dd, J 9.5, $3.3 \mathrm{~Hz}), 5.27(1 \mathrm{H}, \mathrm{t}, J 9.5 \mathrm{~Hz}), 5.24$ $(1 \mathrm{H}, \mathrm{dd}, J 3.2,1.8 \mathrm{~Hz}), 4.81(1 \mathrm{H}, \mathrm{d}, J 1.8 \mathrm{~Hz}), 4.28(1 \mathrm{H}, \mathrm{dd}, J$ 12.2, $5.4 \mathrm{~Hz}), 4.12(1 \mathrm{H}$, dd, J 12.2, $2.5 \mathrm{~Hz}), 3.96(1 \mathrm{H}$, ddd, J 9.5, 5.4, $2.5 \mathrm{~Hz}), 3.81(1 \mathrm{H}$, ddd, J 9.9, 6.8, 5.6 $\mathrm{Hz}), 3.53(1 \mathrm{H}, \mathrm{dd}, J$ 10.0, $6.2 \mathrm{~Hz}), 3.43(2 \mathrm{H}, \mathrm{t}, J 6.5 \mathrm{~Hz}), 2.16(3 \mathrm{H}, \mathrm{s}), 2.11(3 \mathrm{H}, \mathrm{s})$, 
$2.05(3 \mathrm{H}, \mathrm{s}), 2.00(3 \mathrm{H}, \mathrm{s}), 1.94-1.84(2 \mathrm{H}, \mathrm{m})$ ppm; ${ }^{13} \mathbf{C}$ NMR (101 MHz, CDCl $): \delta$ 170.8, 170.2, 170.1, 169.9, 97.8, 69.6, 69.2, 68.8, 66.3, 65.0, 62.7, 48.2, 28.8, 21.0, 20.89, 20.9, $20.8 \mathrm{ppm}$.

\section{3'-Azidopropyl-O-a-D-mannopyranoside 5}

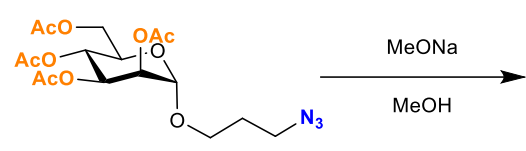

s6

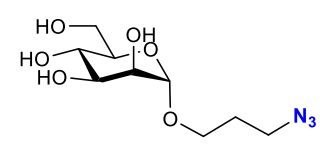

5

To a solution of 3'-azidopropyl-2,3,4,6-O-acetyl- $\alpha$-D-mannopyranoside S6 (164 mg, $0.38 \mathrm{mmol})$ in $\mathrm{MeOH}(2.5 \mathrm{~mL})$ was added $\mathrm{NaOMe}(3 \mathrm{mg}, 0.11 \mathrm{mmol})$ and the reaction stirred for $1 \mathrm{~h}$ until full conversion was observed by TLC. The reaction was neutralised with $\mathrm{H}^{+}$amberlite then filtered and concentrated in vacuo. Column chromatography (silica, $10 \% \mathrm{MeOH}$ in $\mathrm{CH}_{2} \mathrm{Cl}_{2}$ ) afforded 3'-azidopropyl-O- $\alpha$-D-mannopyranoside 5 (90 $\mathrm{mg}, 0.34 \mathrm{mmol}, 90 \%$ ) as a pale yellow oil. Data are in accordance with the literature. ${ }^{[6]}$

${ }^{1} \mathrm{H}$ NMR (400 MHz, CD 3 OD): $\delta 4.75(1 \mathrm{H}, \mathrm{d}, J 1.8 \mathrm{~Hz}), 3.87-3.81(2 \mathrm{H}, \mathrm{m}), 3.80(1 \mathrm{H}$, dd, J 3.3, $1.7 \mathrm{~Hz}), 3.71(1 \mathrm{H}$, dd, J 11.9, $5.6 \mathrm{~Hz}), 3.68(1 \mathrm{H}$, dd, J 9.2, $3.4 \mathrm{~Hz}), 3.61(1 \mathrm{H}$, t, J $9.4 \mathrm{~Hz}), 3.55-3.46(2 \mathrm{H}, \mathrm{m}), 3.41(2 \mathrm{H}, \mathrm{td}, \mathrm{J} 6.8,3.3 \mathrm{~Hz}), 1.86(2 \mathrm{H}, \mathrm{pd}, J$ 6.8, 1.1 $\mathrm{Hz}$ ) ppm. ${ }^{13} \mathrm{C}$ NMR (101 MHz, CD $\left.{ }_{3} \mathrm{OD}\right): \delta 101.7,74.7,72.6,72.1,68.6,65.4,62.9$, 49.5, 29.9 ppm.

\section{7'-Bromoheptyl-2,3,4,6-O-acetyl- $\alpha$-D-mannopyranoside S7}

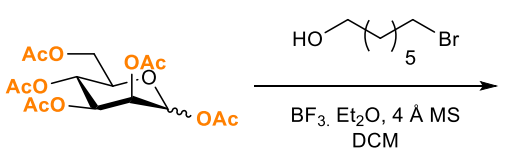

S2

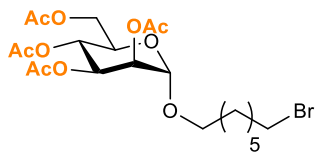

s7

To a solution of mannose pentaacetate $\mathbf{S 2}(1.76 \mathrm{~g}, 4.50 \mathrm{mmol})$ and 3-bromo-1heptanol $(1.32 \mathrm{~g}, 6.75 \mathrm{mmol})$ in dry $\mathrm{CH}_{2} \mathrm{Cl}_{2}(4.50 \mathrm{~mL})$ was added $\mathrm{BF}_{3}$. Et ${ }_{2} \mathrm{O}(2.3 \mathrm{~g}, 16.2$ mmol) dropwise. After $16 \mathrm{~h}$, the $\mathrm{RM}$ was diluted with $\mathrm{CH}_{2} \mathrm{Cl}_{2}$ and washed with $\mathrm{NaHCO}_{3 \text { (aq.) }}$ sat. $(10 \mathrm{~mL})$, water $(10 \mathrm{~mL})$, dried over $\mathrm{MgSO}_{4}$, filtered, concentrated in vacuo and purified by column chromatography (silica, 20\% EtOAc in hexanes 4:1) to give $\mathbf{S 7}$ (591 mg, $1.12 \mathrm{mmol}, 25 \%)$ as a white solid.

\section{Alternative procedure:}

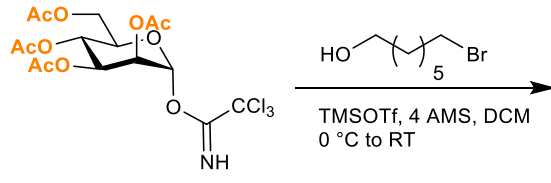

S4

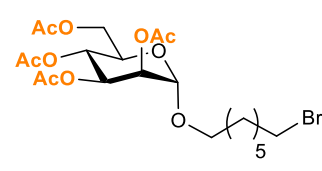

57

To a flask under $\mathrm{N}_{2}$, was added trichloroacetimidate $\mathbf{S 4}(1 \mathrm{~g}, 2.0 \mathrm{mmol})$ and preactivated $4 \AA$ molecular sieves $(2 \mathrm{~g})$. Dry $\mathrm{CH}_{2} \mathrm{Cl}_{2}(15 \mathrm{~mL})$ and bromoheptanol $(0.47 \mathrm{~mL}$, $3.0 \mathrm{mmol}$ ) were added and the reaction stirred for 30 minutes. The reaction was cooled to $0^{\circ} \mathrm{C}$ then TMSOTf $(0.07 \mathrm{~mL}, 0.4 \mathrm{mmol})$ was added dropwise and the reaction stirred at $\mathrm{RT}$ for $3 \mathrm{~h}$. The reaction was quenched with $\mathrm{NEt} 3$ then diluted with $\mathrm{CH}_{2} \mathrm{Cl}_{2}(10 \mathrm{~mL})$, 
filtered over celite and concentrated in vacuo. Purification by column chromatography (silica, 5-15\% acetone in cyclohexane) afforded 7'-bromoheptyl-2,3,4,6- O-acetyl- $\alpha$-Dmannopyranoside $\mathbf{S 7}$ (386 $\mathrm{mg}, 0.76 \mathrm{mmol}, 38 \%$ yield) as a white solid. Data are in accordance with the literature. ${ }^{7]}$

${ }^{1} \mathrm{H}$ NMR $\left.400 \mathrm{MHz}, \mathrm{CDCl}_{3}\right): \delta 5.34(1 \mathrm{H}, \mathrm{dd}, J 9.8,3.3 \mathrm{~Hz}), 5.27(1 \mathrm{H}, \mathrm{t}, J 9.8 \mathrm{~Hz}), 5.23$ $(1 \mathrm{H}, \mathrm{dd}, J 3.3,1.8 \mathrm{~Hz}), 4.80(1 \mathrm{H}, \mathrm{d}, J 1.8 \mathrm{~Hz}), 4.28(1 \mathrm{H}, \mathrm{dd}, J 12.2,5.3 \mathrm{~Hz}), 4.10(1 \mathrm{H}$, dd, J 12.2, 2.4 Hz), 3.98 (1H, ddd, J 9.8, 5.3, 2.4 Hz), 3.68 (1H, dt, J9.6, $6.6 \mathrm{~Hz}), 3.50$ - $3.39(1 \mathrm{H}, \mathrm{dt}, \mathrm{J} 12.9,6.6 \mathrm{~Hz}), 2.16(3 \mathrm{H}, \mathrm{s}), 2.10(3 \mathrm{H}, \mathrm{s}), 2.05(3 \mathrm{H}, \mathrm{s}), 1.99(3 \mathrm{H}, \mathrm{s})$, $1.87(2 \mathrm{H}, \mathrm{d}, \mathrm{J} 6.9 \mathrm{~Hz}), 1.65-1.61(2 \mathrm{H}, \mathrm{m}), 1.50-1.44(2 \mathrm{H}, \mathrm{m}), 1.40-1.32(4 \mathrm{H}, \mathrm{m})$, $1.27-1.23(1 \mathrm{H}, \mathrm{m}) \mathrm{ppm}$.

\section{7'-Azidoheptyl-2,3,4,6-O-acetyl- $\alpha$-D-mannopyranoside S8}

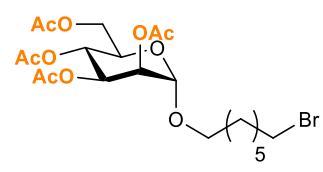

s7

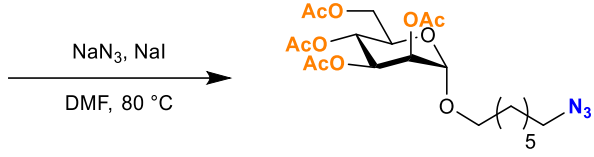

s8

To a solution of bromide $\mathbf{S 7}(591 \mathrm{mg}, 1.12 \mathrm{mmol})$ in DMF $(5 \mathrm{~mL})$ was added $\mathrm{NaN}_{3}$ $(132 \mathrm{mg}, 2.02 \mathrm{mmol})$ and $\mathrm{Nal}(84 \mathrm{mg}, 0.56 \mathrm{mmol})$. The RM was then heated at $80{ }^{\circ} \mathrm{C}$. After $16 \mathrm{~h}$ the RM was allowed to cool down to room temperature and was then diluted with EtOAc $(15 \mathrm{~mL})$, washed with brine $(30 \mathrm{~mL})$, the organic phase was dried over $\mathrm{MgSO}_{4}$, concentrated in vacuo and then purified by column chromatography (silica, $25 \%$ to $33 \%$ EtOAc in hexanes) to give titled compound $\mathbf{S 8}$ (315 mg, $0.64 \mathrm{mmol}, 58 \%$ ) as a pale yellow oil. Data are in accordance with the literature. ${ }^{[7]}$

${ }^{1} \mathrm{H}$ NMR $\left(400 \mathrm{MHz}, \mathrm{CDCl}_{3}\right): \delta 5.28(1 \mathrm{H}, \mathrm{dd}, J 10.0,3.4 \mathrm{~Hz}), 5.21(1 \mathrm{H}, \mathrm{m}), 5.16(1 \mathrm{H}$, dd, J 3.4, $1.8 \mathrm{~Hz}), 4.73(1 \mathrm{H}, \mathrm{d}, J 1.7 \mathrm{~Hz}), 4.21(1 \mathrm{H}, \mathrm{dd}, J 12.2,5.3 \mathrm{~Hz}), 4.04(1 \mathrm{H}, \mathrm{dd}$, J 12.2, $2.5 \mathrm{~Hz}$ ), $3.91(1 \mathrm{H}$, ddd, J 9.9, 5.3, $2.5 \mathrm{~Hz}), 3.61(1 \mathrm{H}, \mathrm{dt}, J$ 9.7, $6.6 \mathrm{~Hz}), 3.38$ $(1 \mathrm{H}, \mathrm{dt}, J$ 9.7, $6.5 \mathrm{~Hz}), 3.20(2 \mathrm{H}, \mathrm{t}, J 6.9 \mathrm{~Hz}), 2.09(3 \mathrm{H}, \mathrm{s}), 2.03(3 \mathrm{H}, \mathrm{s}), 1.98(3 \mathrm{H}, \mathrm{s})$, $1.93(3 \mathrm{H}, \mathrm{s}), 1.59-1.50(5 \mathrm{H}, \mathrm{m}), 1.31(5 \mathrm{H}, \mathrm{dq}, J 5.7,3.1 \mathrm{~Hz}) \mathrm{ppm}$;

\section{7'-O-azidoheptyl a-D-mannopyranoside 6}

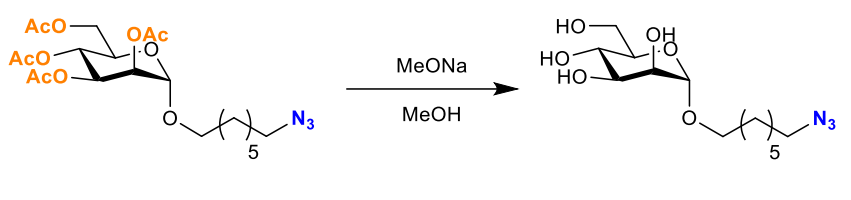

Peracetylated mannoside $\mathbf{S 8}$ (207 mg, $0.65 \mathrm{mmol}$ ) was dissolved in $\mathrm{MeOH}(6.5 \mathrm{~mL}$ ) then $\mathrm{MeONa}(4 \mathrm{mg}, 0.07 \mathrm{mmol})$ was added. After $3 \mathrm{~h}$, the RM was filtered through a plug of celite and concentrated in vacuo to give mannoside $6(208 \mathrm{mg}, 0.65 \mathrm{mmol}$, quant.) as a clear oil. Data are in accordance with the literature. ${ }^{[7]}$

${ }^{1} \mathrm{H}$ NMR (400 MHz, CD $\left.{ }_{3} \mathrm{OD}\right): \delta 4.64(1 \mathrm{H}, \mathrm{d}, J 1.6 \mathrm{~Hz}), 3.73(2 \mathrm{H}, \mathrm{m}), 3.66-3.57(3 \mathrm{H}$, $\mathrm{m}), 3.52(1 \mathrm{H}, \mathrm{t}, J 9.4 \mathrm{~Hz}), 3.46-3.39(1 \mathrm{H}, \mathrm{m}), 3.32(1 \mathrm{H}, \mathrm{dt}, J 9.6,6.2 \mathrm{~Hz}), 3.23-3.15$ $(2 \mathrm{H}, \mathrm{m}), 1.55-1.45(5 \mathrm{H}, \mathrm{m}), 1.37-1.25(5 \mathrm{H}, \mathrm{m}) \mathrm{ppm} ;{ }^{13} \mathrm{C}$ NMR (101 MHz, MeOD): $\delta 100.1,73.2,71.3,70.9,67.2,67.1,62.3,61.4,48.5,47.9,29.1,28.6,29.2,26.0$ ppm.

\section{7'-O-aminoheptyl-a-D-mannopyranoside 1}




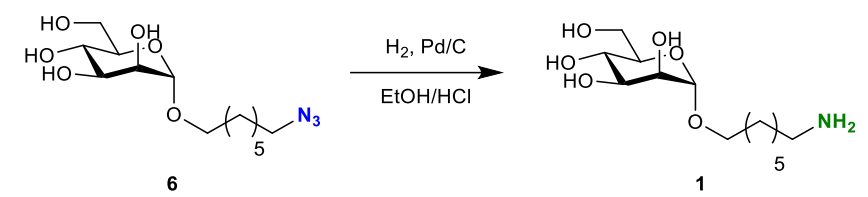

Azide 6 (208 mg, $0.65 \mathrm{mmol}$ ) was dissolved in (19:1) EtOH: $\mathrm{HCl}(2 \mathrm{~mL})$ and the flask was purged three times with $\mathrm{N}_{2}$. $\mathrm{Pd} / \mathrm{C}$ was then added and the flask was placed under $\mathrm{a}_{2}$ atmosphere. After $8 \mathrm{~h}$, the reaction was filtered through a pad of celite and then concentrated in vacuo. The RM was purified by $\mathrm{HPLC}\left(\mathrm{C} 18,5 \% \mathrm{H}_{2} \mathrm{O}\right.$ in $\left.\mathrm{MeCN}\right)$ to give title compound 1 (76 mg, $0.26 \mathrm{mmol}, 40 \%$ ) as a clear oil.

${ }^{1} \mathrm{H}$ NMR (400 MHz, CD $\left.{ }_{3} \mathrm{OD}\right): \delta 4.73(1 \mathrm{H}, \mathrm{d}, J 1.7 \mathrm{~Hz}), 3.82(1 \mathrm{H}, \mathrm{dd}, J 11.7,2.4 \mathrm{~Hz})$, $3.77(1 \mathrm{H}, \mathrm{dt}, J 3.3,1.5 \mathrm{~Hz}), 3.75-3.65(3 \mathrm{H}, \mathrm{m}), 3.60(1 \mathrm{H}, \mathrm{td}, J 9.5,1.2 \mathrm{~Hz}), 3.52(1 \mathrm{H}$, ddd, J 9.6, 5.7, $2.4 \mathrm{~Hz}), 3.46-3.37(3 \mathrm{H}, \mathrm{m}), 2.68-2.61(\mathrm{~m}, 2 \mathrm{H}), 1.57(4 \mathrm{H}$, dd, J 12.6, $6.2 \mathrm{~Hz}), 1.48(1 \mathrm{H}, \mathrm{q}, J 6.9 \mathrm{~Hz}), 1.43-1.31(8 \mathrm{H}, \mathrm{m}) \mathrm{ppm}{ }^{13} \mathrm{C}$ NMR (101 MHz, CD $\left.{ }_{3} \mathrm{OD}\right)$ : $\delta$ 100.2, 73.2, 71.3, 70.9, 70.5, 67.1, 61.5, 41.0, 32.0, 29.3, 29.1, 26.5, 25.9 ppm; HRMS(ES): calcd. for $\mathrm{C}_{13} \mathrm{H}_{27} \mathrm{NO}_{6} 293.18$; found $\mathrm{C}_{13} \mathrm{H}_{27} \mathrm{NO}_{6}{ }^{+} 294.19$.

\section{0'-Bromodecyl-2,3,4,6-O-acetyl-D-mannopyranoside S8}

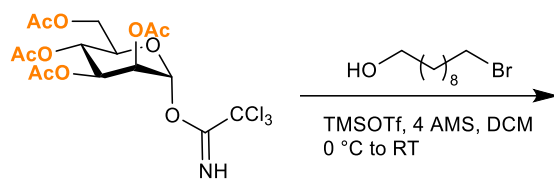

S4

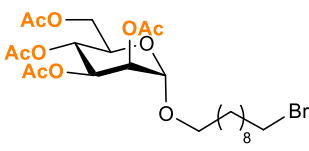

To a solution of trichloroacetimidate $\mathbf{S 4}(1 \mathrm{~g}, 2.0 \mathrm{mmol})$ and pre-activated $4 \AA \AA$ molecular sieves $(2 \mathrm{~g})$ in dry $\mathrm{CH}_{2} \mathrm{Cl}_{2}(15 \mathrm{~mL})$ under $\mathrm{N}_{2}$ was added bromodecanol $(0.60 \mathrm{~mL}, 3.0$ $\mathrm{mmol}$ ). The RM was stirred for 30 minutes then the reaction was cooled to $0{ }^{\circ} \mathrm{C}$ and TMSOTf $(0.07 \mathrm{~mL}, 0.4 \mathrm{mmol})$ was added dropwise. After $16 \mathrm{~h}$ the reaction was quenched with $\mathrm{NEt}_{3}$ then diluted with $\mathrm{CH}_{2} \mathrm{Cl}_{2}(10 \mathrm{~mL})$, filtered over celite, concentrated in vacuo and purified by column chromatography (silica, $0-10 \%$ acetone in cyclohexane) to give 10'-bromodecyl-2,3,4,6-O-acetyl-D-mannopyranoside S8 as a white solid (320 mg, $0.56 \mathrm{mmol}, 28 \%$ ). Data are in accordance with the literature. ${ }^{[8]}$

${ }^{1} \mathrm{H}$ NMR (400 MHz, $\left.\mathrm{CDCl}_{3}\right): \delta 5.35(1 \mathrm{H}, \mathrm{dd}, J 10.0,3.4 \mathrm{~Hz}), 5.27(1 \mathrm{H}, \mathrm{t}, J 10.0 \mathrm{~Hz})$, $5.23(1 \mathrm{H}, \mathrm{dd}, J 3.4,1.8 \mathrm{~Hz}), 4.80(1 \mathrm{H}, \mathrm{d}, J 1.8 \mathrm{~Hz}), 4.28(1 \mathrm{H}, \mathrm{dd}, J 12.2,5.3 \mathrm{~Hz}), 4.10$ $(1 \mathrm{H}$, dd, J 12.2, $2.4 \mathrm{~Hz}), 3.98(1 \mathrm{H}$, ddd, J 10.0, 5.3, $2.4 \mathrm{~Hz}), 3.67(1 \mathrm{H}, \mathrm{dt}, J 9.6,6.8$ $\mathrm{Hz}), 3.48-3.43(1 \mathrm{H}, \mathrm{m}), 3.41(2 \mathrm{H}, \mathrm{t}, J 6.9 \mathrm{~Hz}), 2.16(3 \mathrm{H}, \mathrm{s}), 2.10(3 \mathrm{H}, \mathrm{s}), 2.04(3 \mathrm{H}$, s), $1.99(3 \mathrm{H}, \mathrm{s}), 1.85(2 \mathrm{H}, \mathrm{p}, J 7.0 \mathrm{~Hz}), 1.63-1.55(2 \mathrm{H}, \mathrm{m}), 1.46-1.38(2 \mathrm{H}, \mathrm{m}), 1.35$ $-1.26(10 \mathrm{H}, \mathrm{m}) \mathrm{ppm}$.

\section{0'-azidodecyl-2,3,4,6-O-acetyl-D-mannopyranoside S9}

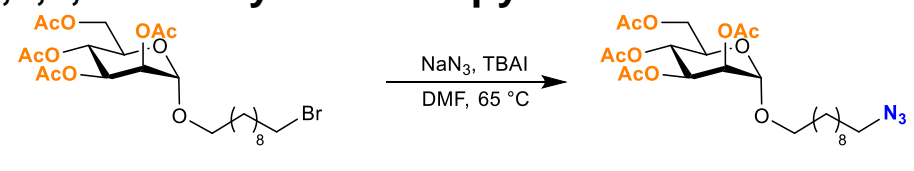

58

s9

To a solution of 10'-bromodecyl-2,3,4,6-O-acetyl-D-mannopyranoside $\mathbf{S 8}$ (300 $\mathrm{mg}$, $0.53 \mathrm{mmol})$ in dry DMF $(5 \mathrm{~mL})$ was added $\mathrm{NaN}_{3}(172 \mathrm{mg}, 2.64 \mathrm{mmol})$ and TBAl (19.5 $\mathrm{mg}, 0.05 \mathrm{mmol}$ ) the reaction was then heated at $65^{\circ} \mathrm{C}$. After $16 \mathrm{~h}$ the RM was then concentrated in vacuo, diluted with $\mathrm{Et}_{2} \mathrm{O}(15 \mathrm{~mL})$, washed with $\mathrm{NaHCO}_{3}$ (aq.) sat. (20 
$\mathrm{mL})$. The aqueous layer was extracted with $\mathrm{Et}_{2} \mathrm{O}(15 \mathrm{~mL})$ then the combined organic extracts were washed with brine $(2 \times 10 \mathrm{~mL})$, dried with $\mathrm{MgSO}_{4}$, filtered, concentrated in vacuo and purified by column chromatography (silica, 5-15\% Acetone in cyclohexane) to yield 10'-azidodecyl-2,3,4,6-O-acetyl-D-mannopyranoside S9 (150 $\mathrm{mg}, 0.28 \mathrm{mmol}, 53.4 \%$ ) as a white solid. Data are in accordance with the literature. ${ }^{[8]}$

${ }^{1} \mathrm{H}$ NMR (400 MHz, CDCl 3$): \delta 5.35(1 \mathrm{H}$, dd, J 10.0, $3.5 \mathrm{~Hz}), 5.27(1 \mathrm{H}, \mathrm{t}, J 10.0 \mathrm{~Hz})$, $5.23(1 \mathrm{H}, \mathrm{dd}, J 3.5,1.8 \mathrm{~Hz}), 4.80(1 \mathrm{H}, \mathrm{d}, J 1.8 \mathrm{~Hz}), 4.28(1 \mathrm{H}, \mathrm{dd}, J 12.3,5.2 \mathrm{~Hz}), 4.10$ $(1 \mathrm{H}, \mathrm{dd}, J$ 12.3, $2.4 \mathrm{~Hz}), 3.98$ 1H, (ddd, J 10.0, 5.2, $2.4 \mathrm{~Hz}), 3.67(1 \mathrm{H}, \mathrm{dt}, J$ 9.6, 6.7 $\mathrm{Hz}), 3.44(1 \mathrm{H}, \mathrm{dt}, J$ 9.6, $6.6 \mathrm{~Hz}), 3.26(2 \mathrm{H}, \mathrm{t}, J 7.0 \mathrm{~Hz}), 2.16(3 \mathrm{H}, \mathrm{s}), 2.10(3 \mathrm{H}, \mathrm{s}), 2.04$ $(3 \mathrm{H}, \mathrm{s}), 1.99(3 \mathrm{H}, \mathrm{s}), 1.64-1.56(2 \mathrm{H}, \mathrm{m}), 1.37-1.27(14 \mathrm{H}, \mathrm{m})$ ppm. ${ }^{13} \mathrm{C}$ NMR (101 $\left.\mathbf{M H z} \mathbf{C D C l}_{3}\right): \delta 170.8,170.3,170.1,169.9,97.7,77.4,69.9,69.3,68.7,68.5,66.4$, $62.7,51.6,29.5,29.5,29.4,29.3,29.0,26.8,26.2,20.90,20.86$ ppm.

10'-azidodecyl-O-D-mannopyranoside 7

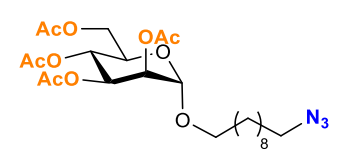

s9

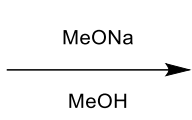

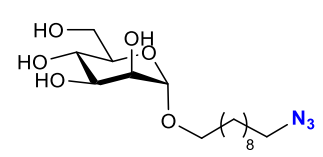

7

To a solution of 10'-azidodecyl-2,3,4,6-O-acetyl-D-mannopyranoside (126 mg, 0.24 $\mathrm{mmol})$ in $\mathrm{MeOH}(2.5 \mathrm{~mL})$ was added NaOMe $(3.9 \mathrm{mg}, 0.072 \mathrm{mmol})$ and the reaction stirred for 30 minutes until full conversion was observed by TLC. The reaction was neutralised with $\mathrm{H}^{+}$amberlite to $\mathrm{pH}=7$ then filtered and concentrated in vacuo. Column chromatography (silica, $10 \% \mathrm{MeOH}$ in $\mathrm{CH}_{2} \mathrm{Cl}_{2}$ ) afforded 10'-azidodecyl-O-Dmannopyranoside 7 (42 mg, $0.12 \mathrm{mmol}, 48 \%$ ). as a white solid. Data are in accordance with the literature. ${ }^{[8]}$

${ }^{1} \mathrm{H}$ NMR (400 MHz, CD $\left.{ }_{3} \mathrm{OD}\right): \delta 4.73(1 \mathrm{H}, \mathrm{d}, J 1.8 \mathrm{~Hz}), 3.82(1 \mathrm{H}, \mathrm{dd}, J 11.7,2.4 \mathrm{~Hz})$, $3.77(1 \mathrm{H}, \mathrm{dd}, J$ J.4, $1.7 \mathrm{~Hz}), 3.75-3.66(3 \mathrm{H}, \mathrm{m}), 3.60(1 \mathrm{H}, \mathrm{t}, J 9.4 \mathrm{~Hz}), 3.52(1 \mathrm{H}$, ddd, J 9.7, 5.8, 2.3 Hz), 3.41 (1H, dt, J 9.5, $6.3 \mathrm{~Hz}), 3.28(2 \mathrm{H}, \mathrm{t}, J 6.8 \mathrm{~Hz}), 1.67-1.53(\mathrm{~m}$,

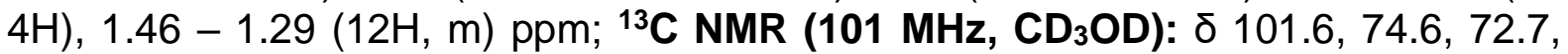
72.3, 68.6, 68.6, 62.92, 52.5, 30.6 (3C), 30.5, 30.3, 29.9, 27.8, 27.3 ppm.

\section{Determination of glycan coated microspheres using CuAAC}

Adapting the protocol described by Finn and co-workers in 2011, ${ }^{[9]}$ the determination of the efficiency of bioconjugation using CuAAC was carried out. Two experiments were carried out, the first step was aimed to confirm that the fluorescence of S12 was not affected by the presence of the microspheres. The second experiment was to confirm that the click reaction occurred efficiently on the beads.

First step: CuAAC reaction of non-fluorescent coumarin and propargyl amine in presence and absence of microspheres. 


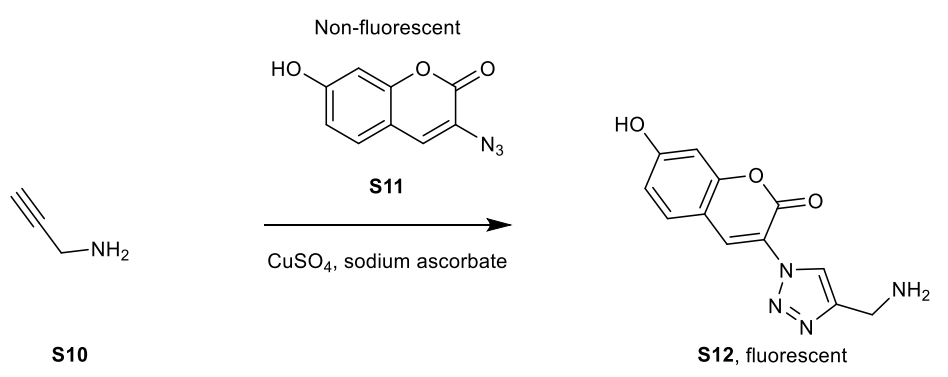

To a PBS solution of propargylamine S10 $(446 \mu \mathrm{L}, 560 \mu \mathrm{M})$ in a $2 \mathrm{~mL}$ Eppendorf, a PBS solution of azidocoumarin $\mathbf{S 1 1}$ (10 $\mu \mathrm{L}$ of a $5 \mathrm{mM}$ solution) was added followed by the addition of a PBS solution of $\mathrm{CuSO}_{4}(6.3 \mu \mathrm{L}$ from a $20 \mathrm{mM}$ solution) and sodium ascorbate (25 $\mu \mathrm{L}$ of a $100 \mathrm{mM}$ solution). After $16 \mathrm{~h}, \mathbf{S 1 2}$ was formed, and the reaction was diluted to $1.95 \mathrm{~mL}$ of PBS to reach a concentration of $25 \mu \mathrm{M}$.

As a control, the same experiment was performed without adding the $\mathrm{CuSO}_{4}$ solution. The two samples $\mathbf{S 1 2}$ and the control were then mixed with and without microspheres and the fluorescence measured on a plate reader (excitation $=355 \mathrm{~nm}$; emission = $460 \mathrm{~nm})$.

The results are presented in the table below.

\begin{tabular}{|l|l|l|}
\hline & Without beads $(25 \mu \mathrm{M})$ & With beads $(13 \mu \mathrm{M})$ \\
\hline PBS & 0 & 0 \\
\hline Control & 4634 & 3842 \\
\hline CuAAC & 110811 & 65519 \\
\hline
\end{tabular}

The difference in fluorescence between the control and $\mathrm{S} 12$ shows that the reaction proceeded as expected and that the beads did not interfere with the emission fluorescence.

\section{Second step: CuAAC reaction between propargylated beads with azido- coumarin.}

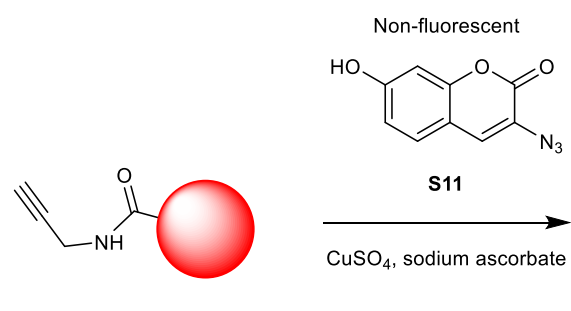

S13

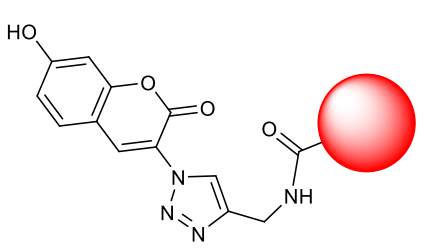

S14, fluorescent

The second reaction was performed with propargylated microspheres (see materials and methods for their synthesis).

A solution of azido-coumarin S11 ( $25 \mu \mathrm{L}$ of a $0.56 \mathrm{mM}$ solution in PBS) was added to a PBS suspension of propargylated beads $\mathbf{S} 13(4 \% \mathrm{w} / \mathrm{v}, 500 \mu \mathrm{L})$ followed by a freshly prepared solution of sodium ascorbate $(63 \mu \mathrm{L}$ of a $5.8 \mathrm{mM}$ solution in PBS), placed under $\mathrm{N}_{2}$ then shaken for $10 \mathrm{~min}$. A CuSO 4 solution $(50 \mu \mathrm{L}$ of $1.43 \mathrm{mM}$ ) was then added, the RM was placed under $\mathrm{N}_{2}$ atm then shaken for $16 \mathrm{~h}$. The RM was already at $25 \mu \mathrm{M}$ and was used without dilution on the plate reader.

A similar reaction was performed without adding the $\mathrm{CusO}_{4}$ solution. 
The two samples were then analysed on a BMG microplate reader and the fluorescence recorded (excitation $=355 \mathrm{~nm}$; emission $=460 \mathrm{~nm}$ ).

The results are presented in the table below.

\begin{tabular}{|l|l|}
\hline & \multicolumn{1}{|c|}{$\begin{array}{c}\text { Reaction on propargylated } \\
\text { beads }(25 \mu \mathrm{M})\end{array}$} \\
\hline Coumarin on PBS & 0 \\
\hline S13 Control (without Cu) & 21658 \\
\hline S13 + CuAAC & 57520 \\
\hline
\end{tabular}

Here again, the difference in fluorescence is a good indication that the reaction was successful.

Glycosylated microspheres were subjected to the CuAAc reaction with coumarin and measure the fluorescence as before. No significant differences in fluorescence were observed when compared with controls, while unfunctionalized alkyne-bearing microbeads showed an increased in fluorescence upon reaction with coumarin, demonstrated the conjugation took place.

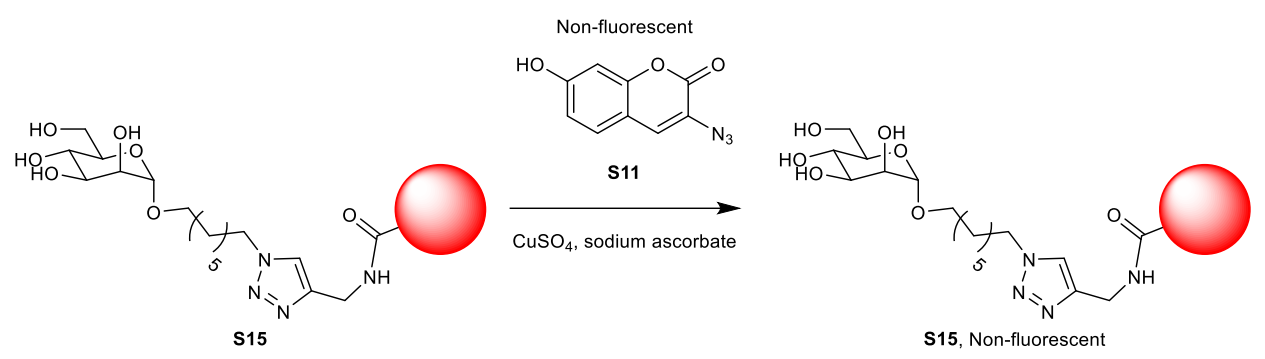

\begin{tabular}{|l|l|}
\hline & \multicolumn{1}{|c|}{$\begin{array}{c}\text { Reaction on C7-Man beads (25 } \\
\mu \mathrm{M})\end{array}$} \\
\hline $\begin{array}{l}\text { Comumarin on PBS } \\
\begin{array}{l}\text { S15 Control (without } \\
\text { copper) }\end{array}\end{array}$ & 0 \\
\hline S15 + CuAAC & 15045 \\
\hline
\end{tabular}

Coumarin Tests

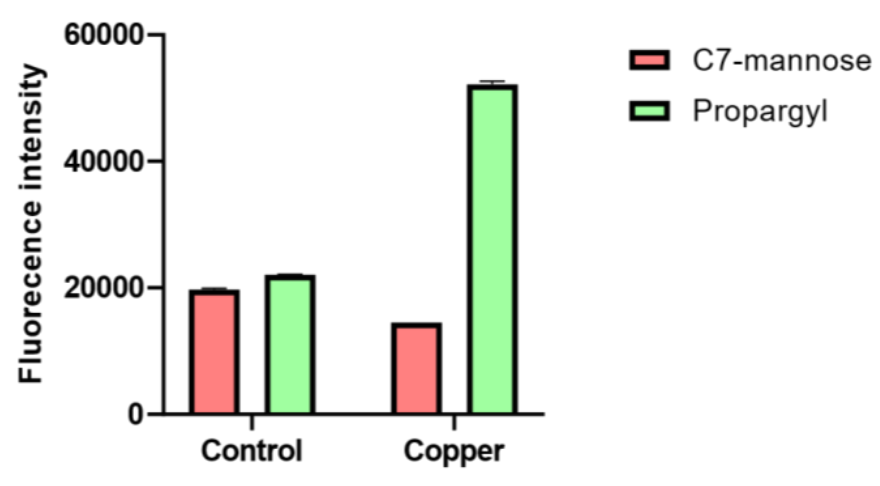




\section{XPS data:}

In addition to the fluorescence experiment, XPS experiments were carried out on conjugated and non-conjugated beads by the National Physics Laboratory (NPL): The Oxygen and Nitrogen content was quantified and compared between the unconjugated microspheres and the C7-conjugated ( $\mathbf{3}$ and $\mathbf{9})$.

Spectrum of unconjugated microspheres:

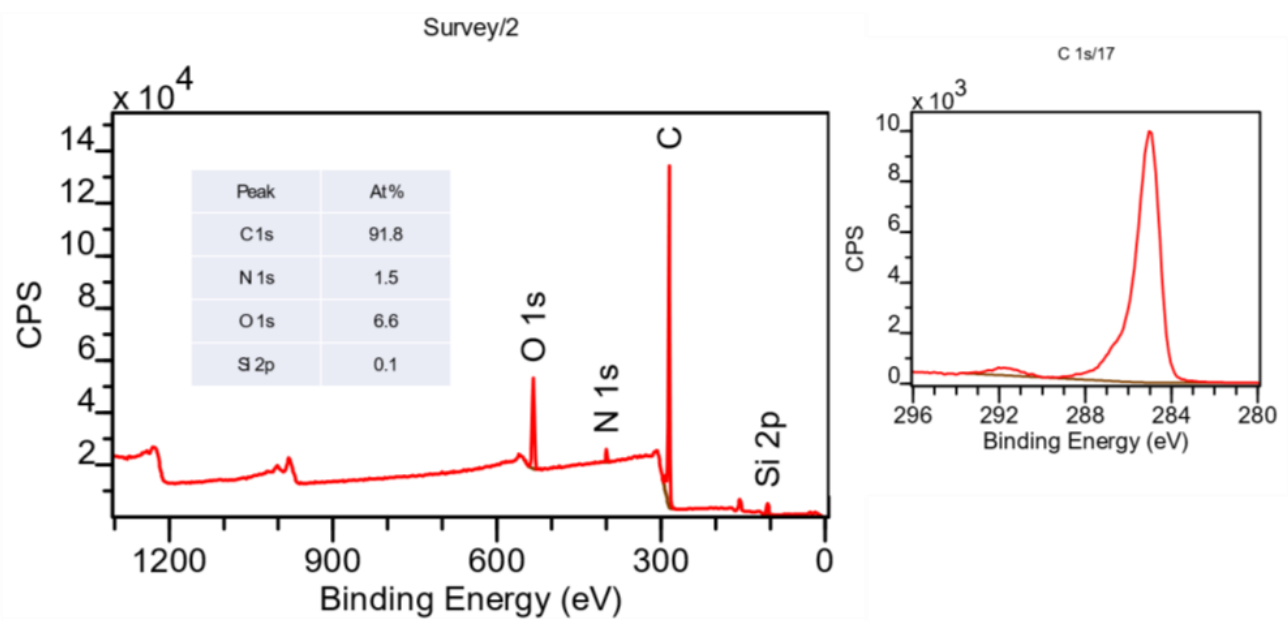

Spectrum of EDC C7-conjugated microspheres (3)

Survey/12
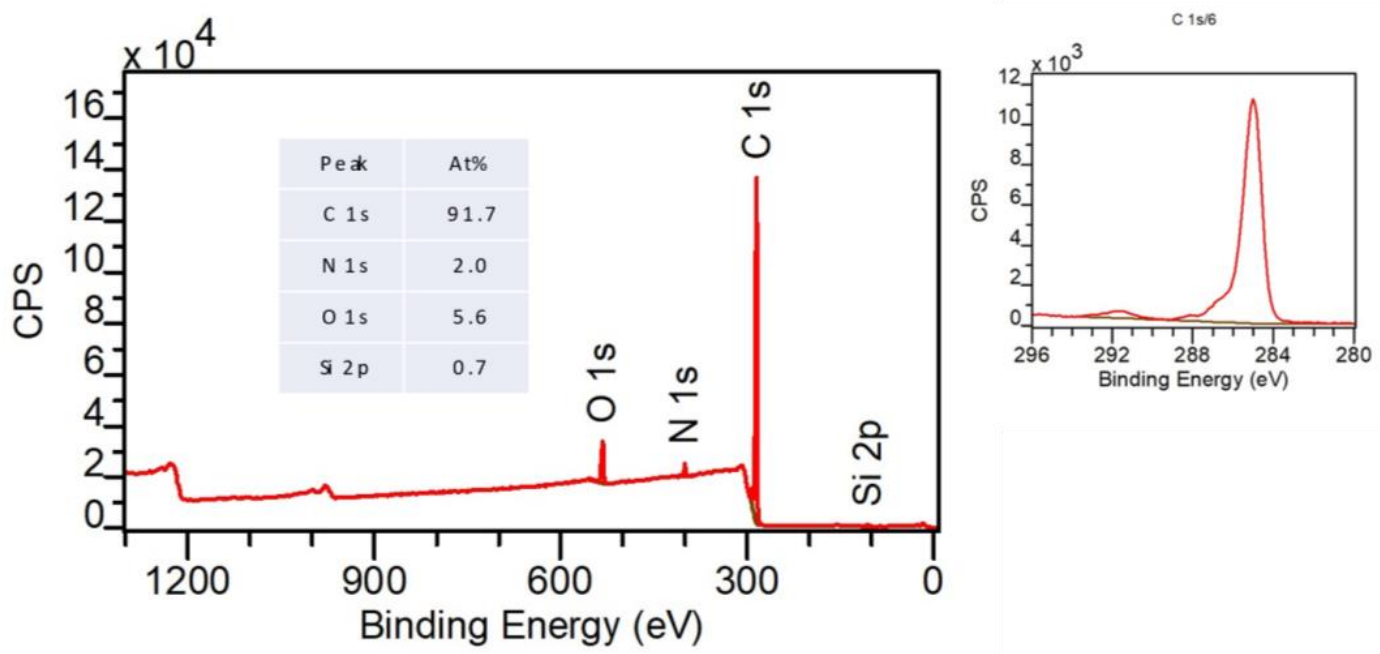

Spectrum of CuAAC C7-conjugated microspheres (9) 


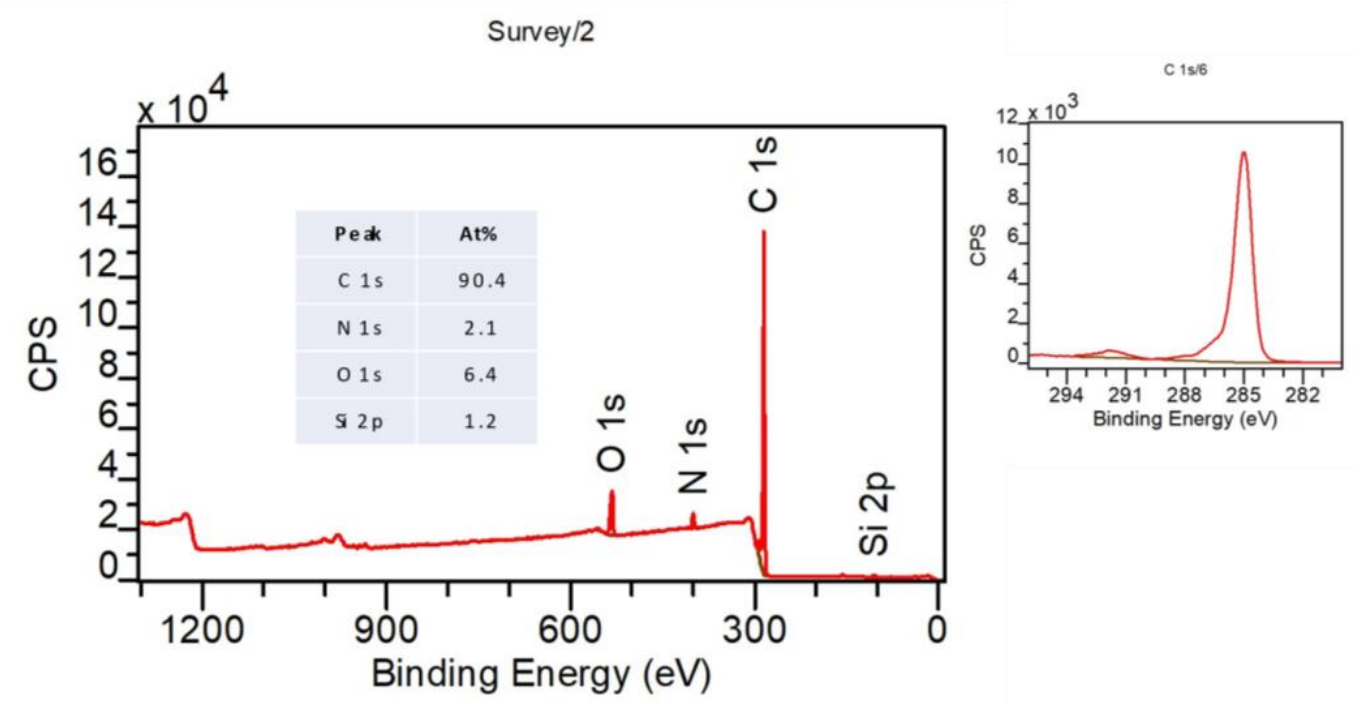

By comparing the amount of Oxygen in the different samples the overlayer thickness was estimated at $\sim 1 \mathrm{~nm}$.

\section{References chemistry experimental}

[1] Kleeb, S.; Pang, L.; Mayer, K.; Eris, D.; Sigl, A.; Preston, R. C.; Zihlmann, P.; Sharpe, T.; Jakob, R. P.; Abgottspon, D.; Hutter, A. S.; Scharenberg, M.; Jiang, X.; Navarra, G.; Rabbani, S.; Smiesko, M.; Lüdin, N.; Bezençon, J.; Schwardt, O.; Maier, T.; Ernst, B. FimH Antagonists: Bioisosteres to improve the in vitro and in vivo PK/PD profile. J. Med. Chem. 2015, 58, 2221-2239.

[2] Ramtohul, Y. K. ; Das Sanjoy, K.; Cadilhac, C.; Reddy, T. J.; Vaillancourt, L.; Gallant, M.; Liu, B.; Dietrich, E.; Vallee, F.; Martel, J.; Poisson, C. Mannose derivatives for treating bacterial infections. WO2014100158A1, 2014.

[3] Hribernik, N.; Tamburrini, A.; Falletta, E.; Bernardi, A. One Pot Synthesis of Thio Glycosides via Aziridine Opening Reactions. Org. Biomol. Chem. 2021, 19, 233247.

[4] Sudibya, H. G.; Ma, J.; Dong, X.; Ng, S.; Li, L.-J.; Liu, X.-W.; Chen, P. Interfacing Glycosylated Carbon-Nanotube-Network Devices with Living Cells to Detect Dynamic Secretion of Biomolecules. Angew. Chemie Int. Ed. 2009, 48, 2723-2726.

[5] Schuster, H. J.; Vijayakrishnan, B.; Davis, B. G. Chain-Growth Polyglycosylation: Synthesis of Linker-Equipped Mannosyl Oligomers. Carbohydr. Res. 2015, 403, 35-141.

[6] Szekely, T.; Roy, O.; Dériaud, E.; Job, A.; Lo-Man, R.; Leclerc, C.; Taillefumier, C. Design, Synthesis, and Immunological Evaluation of a Multicomponent Construct Based on a Glycotripeptoid Core Comprising B and T Cell Epitopes and a Toll-like Receptor 7 Agonist That Elicits Potent Immune Responses. J. Med. Chem. 2018, 61, 9568-9582.

[7] Yan, X.; Delgado, M.; Fu, A.; Alcouffe, P.; Gouin, S. G.; Fleury, E.; Katz, J. L.; Ganachaud, F.; Bernard, J. Simple but Precise Engineering of Functional 
Nanocapsules through Nanoprecipitation. Angew. Chemie Int. Ed. 2014, 53, 69106913.

[8] Grabosch, C.; Kleinert, M.; Lindhorst, T. Glyco-SAMs by 'Dual Click': ThioureaBridged Glyco-OEG Azides for Cycloaddition on Surfaces. Synthesis (Stuttg). 2010, 5, 828-836.

[9] Presolski, S. I.; Hong, V. P.; Finn, M. G. Copper-Catalyzed Azide-Alkyne Click Chemistry for Bioconjugation. Curr. Protoc. Chem. Biol. 2011, 3, 153-162.

\section{Image analysis experimental}

1 Morphological reconstruction algorithm (Old method)

\subsection{Image analysis}

Matlab was used to develop this code. Each image is converted to a gray scale then to binary (Figure 1). This conversion is to improve the image contrast. Morphological structuring is used to approximate the features to a disc with a centroid, length, width and area. This will enable the identification of single free-floating beads and clusters. The parameters calculated are in pixel. These values are converted to micron by multiplying the pixel number with a conversion factor of 0.324 obtained from the microscope. 


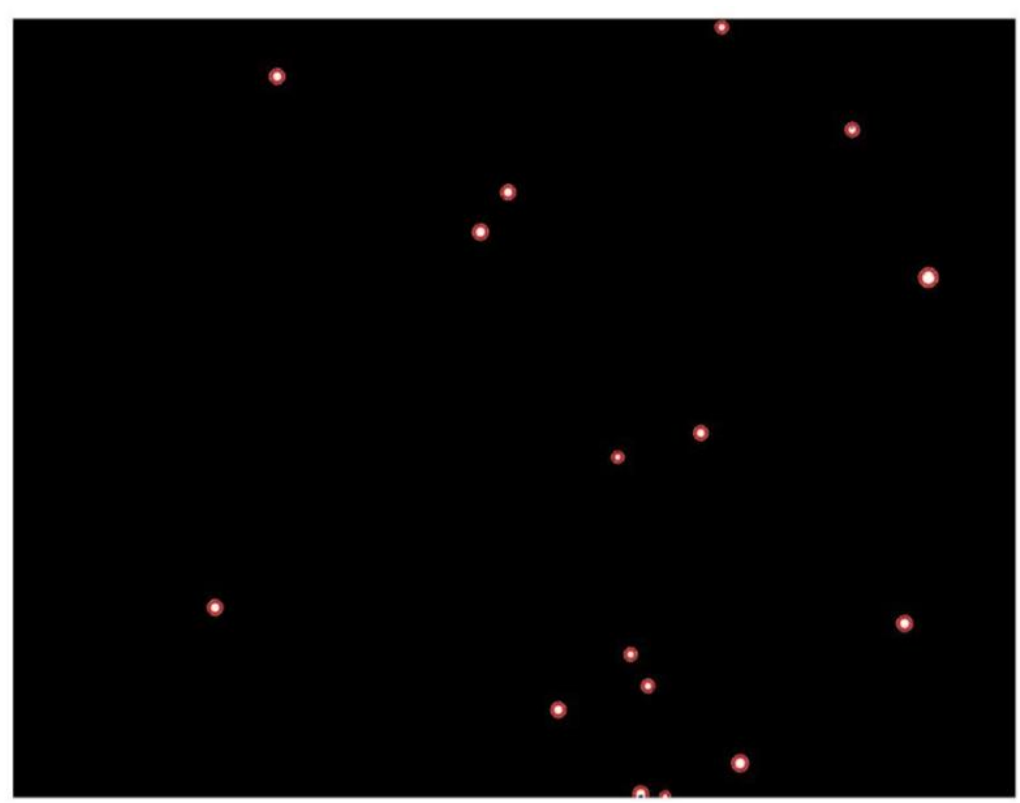

Figure 1: binary image with red circle reconstructed and plotted for visual inspection.

\subsubsection{Single beads}

From the conversion factor, $\sim 3$ pixels represent $1 \mu \mathrm{m}$ and since the structuring element decompositions used for the 'disk' shape is an approximation, an error margin was needed for the length=width criteria.

Although the bead size is quoted as $10 \mu \mathrm{m}$, it was observed that the beads varied in size and the variance was not stated in the datasheet. Therefore, with the circle criteria defined above, a representative size range for beads was determined with images from blanks by plotting the cumulative distribution function (CDF).

To be considered a single bead the following criteria had to be met:

- $\quad \mid$ length-width $\mid \leq 2 \mu \mathrm{m}$

- Length or width $\leq 20 \mu \mathrm{m}$

\subsubsection{Clusters}

Cluster were also identified by morphology and size. Given the bead radius cut-off is $20 \mu \mathrm{m}$, the area threshold is equal to $314.2 \mu \mathrm{m}^{2}$.

To be considered a cluster the following criteria had to be met:

- $\quad \mid$ length-width $\mid>2 \mu \mathrm{m}$

- Length or width greater than $20 \mu \mathrm{m}$

- Area $>314.2 \mu \mathrm{m}^{2}$ 


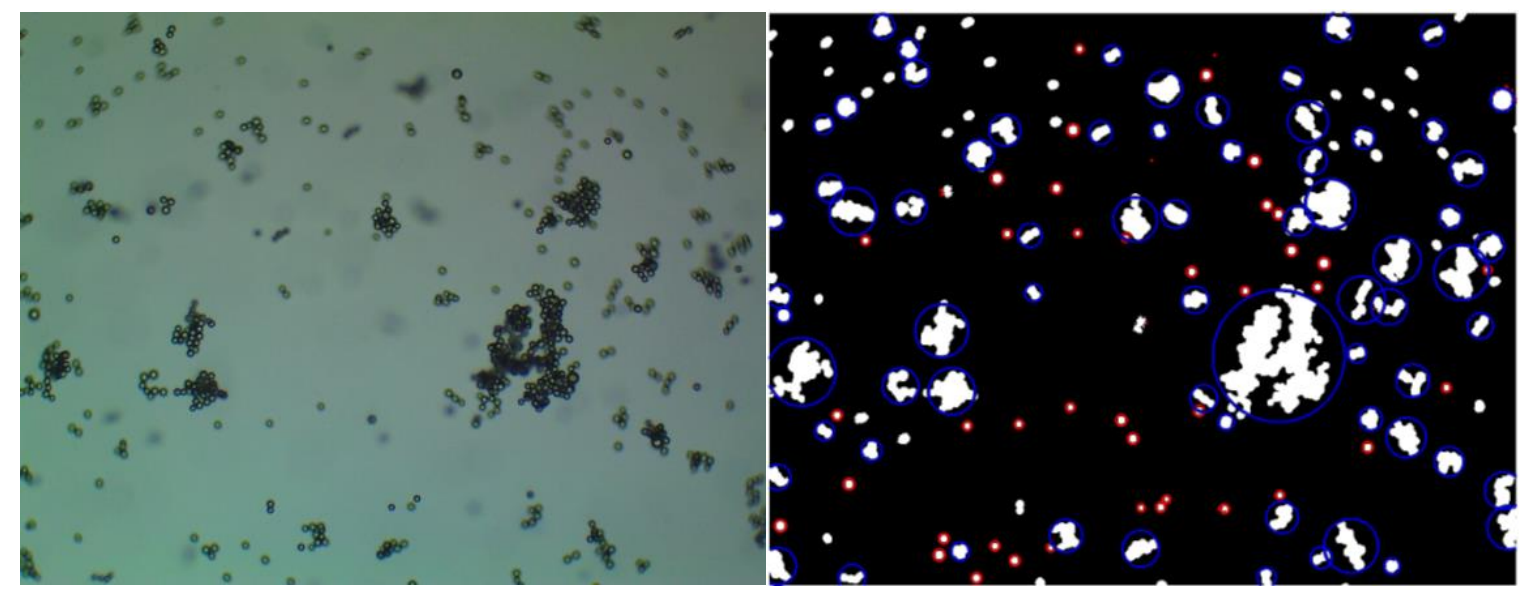

Figure 2: Sample image with clusters: original (left) and processed (right)

Image processing relies on contrast to differentiate cluster from beads, out of focus images adversely impacts contrast. Blurred images or beads that settle next to each other generate false clusters when the image is processed, Figure 3.

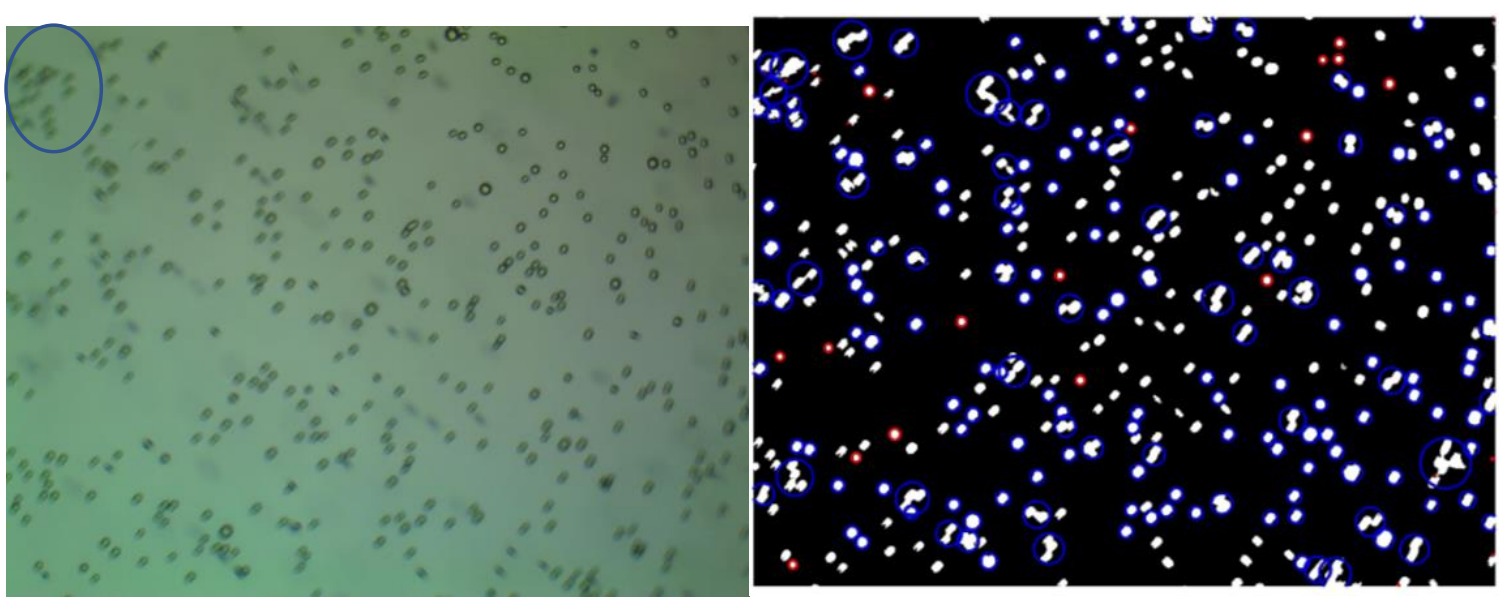

Figure 3: sample images showing the impact of blurring on morphology structuring.

1.1.3 Data analysis

In this method, the following variables are used to analyse the data collected from the images:

Total Area of Clusters (TAC) is the sum of the area of all genuine clusters identified in a sample.

$\mathrm{SNR}_{\mathrm{TAC}}=\frac{\text { average of total area of cluster in positive samples }}{\text { average of total area of clusters in blank }}$

\section{Particle tracking algorithm (New method using Abacus)}

This algorithm was developed using Python. The agglutination process i.e., clustering is assessed from the position of single beads. 
Disclaimer: Abacus is an IP protected software from FluoretiQ Ltd, for further details and access to the software, please contact FluoretiQ at info@fluoretiQ.com

\subsection{Image analysis}

\subsubsection{Bead detection}

Conventional computer algorithms allow the detection of single spherical beads in a colloidal suspension. As a result, the position coordinates of beads can be extracted, even at different at times for trajectory reconstruction. The identification process consists of image pre-processing to enhance the intensity of beads. The preprocessing consists of a series of operations, such as convolution and dilation of the image. First, an RGB image is separated into three channels, and the channel with best contrast between background and beads is selected. A gaussian filter that blurs the image in order to reduce noise is then applied. Later, a convolution between the image and a generated circular mask is applied to enhance the circular shape of semicircular objects. In addition, a low pass filter is applied in order to obtain bright circular objects on a black background.

The position of each particle is then accessed with subpixel accuracy as the centre of mass is identified from the intensity signal of the bright circular objects.
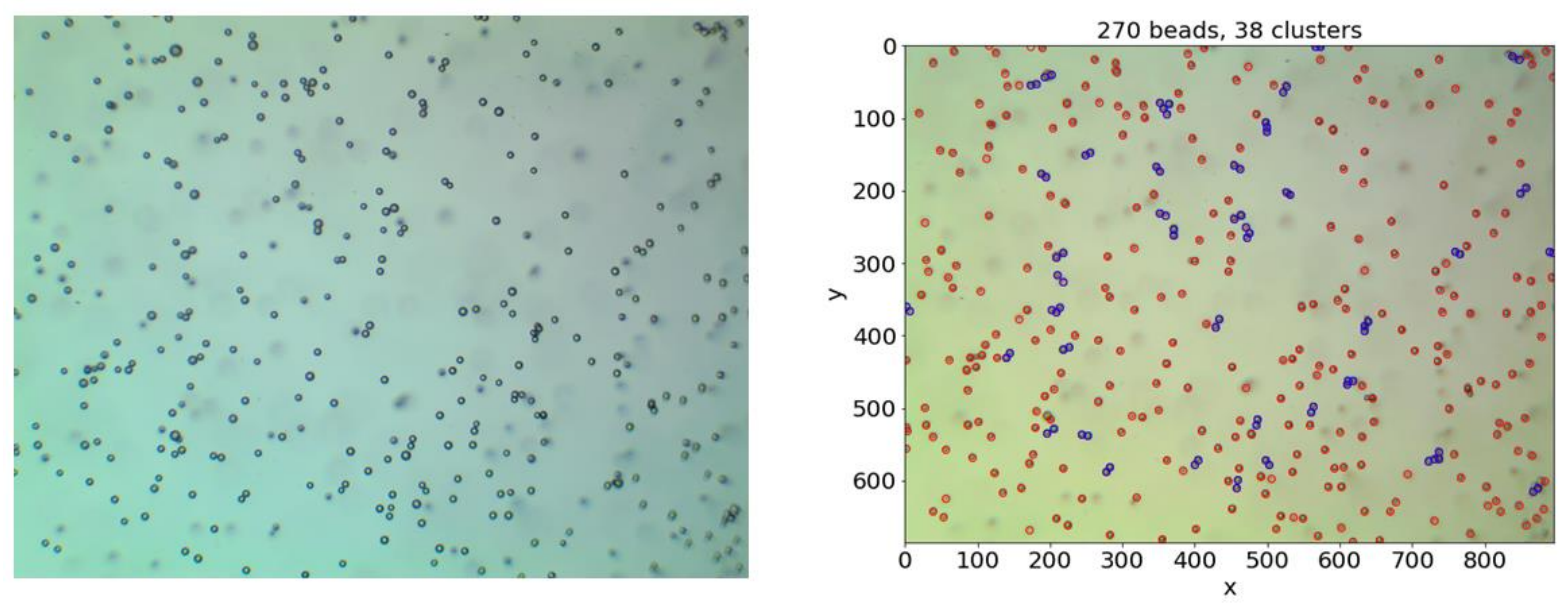

Figure 4. Left: Original sample image. Right: Analysed image containing isolated beads (red) and clusters (blue).

\subsubsection{Cluster}

Having access to the individual coordinates, clustering can be identified from the separation between beads. Two or beads are considered a cluster if they are less than 1 bead length apart. It is worth nothing that the cluster detection might fail for clusters made of beads of different size.

\subsubsection{Data analysis}

The following variables are used to analyse the data collected from the images: 
Total Cluster Size (TCS) is the sum of beads in all genuine clusters identified in a sample.

$\mathrm{SNR}_{\mathrm{TCS}}=\frac{\text { average of total cluster sizes in positive samples }}{\text { average number of total cluster size in blank }}$

Cluster to beads ratio (CBR) is the number of clusters detected divided by the number of single beads detected

$\mathrm{CBR}=\frac{\text { average of clusters detected }}{\text { average of single beads detected }}$

\section{Data generated from the assay}

\section{Conjugation type comparison data}

Table S1. Comparison of EDC microspheres (3) and CuAAC microspheres (9) using E. coli BW25113 in TSB. blank samples were incubated with the microspheres in TSB only.

\begin{tabular}{|c|c|c|c|c|}
\hline Probe & $\begin{array}{c}\text { Concentration } \\
(\mathrm{cfu} / \mathrm{ml})\end{array}$ & $\begin{array}{l}\text { Sample } \\
\text { number }\end{array}$ & Data name & Total_Cluster_Size \\
\hline \multirow{26}{*}{ EDC } & \multirow{9}{*}{0} & \multirow{3}{*}{1} & B_7CM_10x_1-0002 & 4 \\
\hline & & & B_7CM_10x_1-0003 & 14 \\
\hline & & & B_7CM_10x_1-0004 & 6 \\
\hline & & \multirow{3}{*}{2} & B_7CM_10x_2-0002 & 4 \\
\hline & & & B_7CM_10x_2-0003 & 16 \\
\hline & & & B_7CM_10x_2-0004 & 28 \\
\hline & & \multirow{3}{*}{3} & B_7CM_10x_3-0002 & 10 \\
\hline & & & B_7CM_10x_3-0003 & 0 \\
\hline & & & B_7CM_10x_3-0004 & 12 \\
\hline & \multirow{9}{*}{$10^{5}$} & \multirow{3}{*}{1} & 5_E.c_Bw25113_7CM_10x_1-0002 & 13 \\
\hline & & & 5_E.c_Bw25113_7CM_10x_1-0003 & 11 \\
\hline & & & 5_E.c_Bw25113_7CM_10x_1-0004 & 28 \\
\hline & & \multirow{3}{*}{2} & 5_E.c_Bw25113_7CM_10x_2-0002 & 11 \\
\hline & & & 5_E.c_Bw25113_7CM_10x_2-0003 & 28 \\
\hline & & & 5_E.c_Bw25113_7CM_10x_2-0004 & 37 \\
\hline & & \multirow{3}{*}{3} & 5_E.c_Bw25113_7CM_10x_3-0002(2) & 6 \\
\hline & & & 5_E.c_Bw25113_7CM_10x_3-0003(2) & 14 \\
\hline & & & 5_E.c_Bw25113_7CM_10x_3-0004(2) & 16 \\
\hline & \multirow{8}{*}{$10^{6}$} & \multirow{3}{*}{1} & 6_E.c_Bw25113_7CM_10x_1-0002 & 66 \\
\hline & & & 6_E.c_Bw25113_7CM_10x_1-0003 & 54 \\
\hline & & & 6_E.c_Bw25113_7CM_10x_1-0004 & 169 \\
\hline & & \multirow{3}{*}{2} & 6_E.c_Bw25113_7CM_10x_2-0002 & 40 \\
\hline & & & 6_E.c_Bw25113_7CM_10x_2-0003 & 55 \\
\hline & & & 6_E.c_Bw25113_7CM_10x_2-0004 & 66 \\
\hline & & \multirow{2}{*}{3} & 6_E.c_Bw25113_7CM_10x_3-0002(2) & 58 \\
\hline & & & 6_E.c_Bw25113_7CM_10x_3-0003(2) & 74 \\
\hline
\end{tabular}




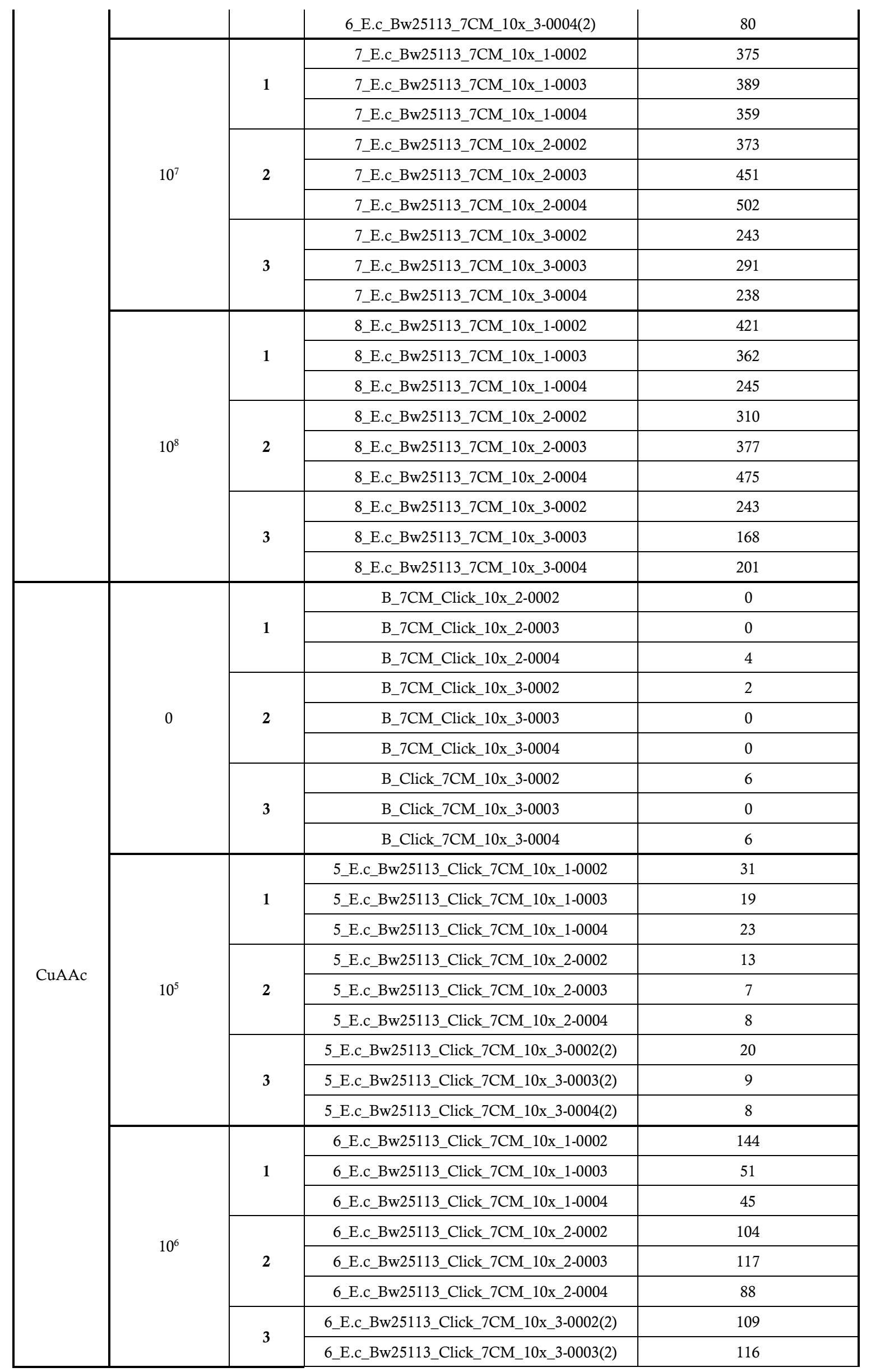




\begin{tabular}{|c|c|c|c|}
\hline & & 6_E.c_Bw25113_Click_7CM_10x_3-0004(2) & 130 \\
\hline \multirow{9}{*}{$10^{7}$} & \multirow{3}{*}{1} & 7_E.c_Bw25113_Click_7CM_10x_1-0002 & 252 \\
\hline & & 7_E.c_Bw25113_Click_7CM_10x_1-0003 & 158 \\
\hline & & 7_E.c_Bw25113_Click_7CM_10x_1-0004 & 241 \\
\hline & \multirow{3}{*}{2} & 7_E.c_Bw25113_Click_7CM_10x_2-0002 & 102 \\
\hline & & 7_E.c_Bw25113_Click_7CM_10x_2-0003 & 183 \\
\hline & & 7_E.c_Bw25113_Click_7CM_10x_2-0004 & 216 \\
\hline & \multirow{3}{*}{3} & 7_E.c_Bw25113_Click_7CM_10x_3-0002 & 188 \\
\hline & & 7_E.c_Bw25113_Click_7CM_10x_3-0003 & 149 \\
\hline & & 7_E.c_Bw25113_Click_7CM_10x_3-0004 & 223 \\
\hline \multirow{9}{*}{$10^{8}$} & \multirow{3}{*}{1} & 8_E.c_Bw25113_Click_7CM_10x_1-0002 & 258 \\
\hline & & 8_E.c_Bw25113_Click_7CM_10x_1-0003 & 193 \\
\hline & & 8_E.c_Bw25113_Click_7CM_10x_1-0004 & 200 \\
\hline & \multirow{3}{*}{2} & 8_E.c_Bw25113_Click_7CM_10x_2-0002 & 291 \\
\hline & & 8_E.c_Bw25113_Click_7CM_10x_2-0003 & 238 \\
\hline & & 8_E.c_Bw25113_Click_7CM_10x_2-0004 & 278 \\
\hline & \multirow{3}{*}{3} & 8_E.c_Bw25113_Click_7CM_10x_3-0002 & 253 \\
\hline & & 8_E.c_Bw25113_Click_7CM_10x_3-0003 & 361 \\
\hline & & 8_E.c_Bw25113_Click_7CM_10x_3-0004 & 249 \\
\hline
\end{tabular}

\section{Strain to strain variability data}

Table S2. Strain/strain variability of agglutination assay with C7-mannose CuAAC (9). E. coli strains BW25113, NCTC 9001, NCTC 13958, J96, NCTC 12241 and $\triangle$ fimA were used, alongside a TSB-only negative control.

\begin{tabular}{|c|c|c|c|c|c|c|c|c|c|c|}
\hline \multirow[b]{2}{*}{ Species } & \multirow[b]{2}{*}{$\begin{array}{l}\text { Biological } \\
\text { replicate }\end{array}$} & \multirow[b]{2}{*}{$\begin{array}{l}\text { Technical } \\
\text { replicate }\end{array}$} & \multicolumn{8}{|c|}{ E. coli strain (Total cluster size) } \\
\hline & & & BW25113 & NCTC 9001 & $\begin{array}{l}\text { NCTC } \\
13958 \\
\end{array}$ & J96 & CFT073 & $\begin{array}{l}\text { NCTC } \\
12241 \\
\end{array}$ & $\Delta$ fimA & TSB \\
\hline \multirow{25}{*}{ E. coli } & \multirow{15}{*}{1} & \multirow{5}{*}{1} & 181 & 163 & 183 & 191 & 287 & 322 & 8 & 4 \\
\hline & & & 260 & 102 & 190 & 520 & 213 & 258 & 10 & 2 \\
\hline & & & 273 & 112 & 207 & 490 & 214 & 236 & 14 & 25 \\
\hline & & & 326 & 138 & 232 & 599 & 396 & 253 & 16 & 18 \\
\hline & & & 287 & 212 & 245 & 655 & 370 & 240 & 51 & 19 \\
\hline & & \multirow{5}{*}{2} & 168 & 179 & 304 & 513 & 408 & 121 & 4 & 0 \\
\hline & & & 255 & 209 & 294 & 358 & 247 & 273 & 14 & 6 \\
\hline & & & 251 & 243 & 311 & 528 & 252 & 256 & 16 & 2 \\
\hline & & & 321 & 191 & 310 & 523 & 77 & 218 & 14 & 6 \\
\hline & & & 308 & 227 & 324 & 561 & 253 & 189 & 23 & 15 \\
\hline & & \multirow{5}{*}{3} & 285 & 192 & 262 & 394 & 278 & 244 & 0 & 0 \\
\hline & & & 264 & 289 & 205 & 445 & 438 & 208 & 12 & 2 \\
\hline & & & 351 & 306 & 157 & 609 & 413 & 199 & 13 & 8 \\
\hline & & & 321 & 339 & 246 & 460 & 350 & 263 & 22 & 10 \\
\hline & & & 465 & 394 & 412 & 552 & 467 & 238 & 19 & 2 \\
\hline & \multirow{10}{*}{2} & \multirow{5}{*}{1} & 254 & 120 & 247 & 244 & 293 & 126 & 4 & 2 \\
\hline & & & 412 & 93 & 359 & 318 & 421 & 195 & 26 & 14 \\
\hline & & & 340 & 149 & 299 & 439 & 329 & 185 & 27 & 28 \\
\hline & & & 361 & 105 & 488 & 343 & 247 & 312 & 26 & 18 \\
\hline & & & 300 & 106 & 287 & 168 & 472 & 400 & 6 & 25 \\
\hline & & \multirow{5}{*}{2} & 249 & 283 & 182 & 343 & 367 & 248 & 22 & 23 \\
\hline & & & 379 & 286 & 208 & 453 & 396 & 216 & 12 & 13 \\
\hline & & & 483 & 330 & 236 & 649 & 452 & 240 & 29 & 14 \\
\hline & & & 520 & 280 & 136 & 521 & 493 & 271 & 23 & 26 \\
\hline & & & 232 & 325 & 195 & 305 & 536 & 261 & 6 & 14 \\
\hline
\end{tabular}




\begin{tabular}{|c|c|c|c|c|c|c|c|c|c|}
\hline & \multirow{5}{*}{3} & 287 & 356 & 279 & 227 & 453 & 374 & 8 & 4 \\
\hline & & 240 & 369 & 363 & 434 & 362 & 252 & 8 & 6 \\
\hline & & 278 & 428 & 252 & 468 & 318 & 481 & 18 & 16 \\
\hline & & 445 & 265 & 320 & 307 & 492 & 500 & 12 & 22 \\
\hline & & 370 & 307 & 243 & 548 & 430 & 472 & 0 & 8 \\
\hline \multirow{15}{*}{3} & \multirow{5}{*}{1} & 232 & 305 & 263 & 127 & 248 & 122 & 22 & 5 \\
\hline & & 173 & 238 & 204 & 531 & 270 & 181 & 32 & 2 \\
\hline & & 267 & 315 & 209 & 113 & 369 & 144 & 14 & 23 \\
\hline & & 282 & 274 & 263 & 251 & 326 & 175 & 54 & 2 \\
\hline & & 221 & 345 & 264 & 513 & 250 & 279 & 50 & 19 \\
\hline & \multirow{5}{*}{2} & 284 & 208 & 237 & 219 & 214 & 120 & 4 & 8 \\
\hline & & 320 & 200 & 256 & 395 & 263 & 192 & 4 & 6 \\
\hline & & 407 & 230 & 371 & 393 & 291 & 238 & 8 & 12 \\
\hline & & 358 & 242 & 476 & 515 & 290 & 255 & 7 & 4 \\
\hline & & 403 & 209 & 340 & 328 & 296 & 253 & 30 & 4 \\
\hline & \multirow{5}{*}{3} & 351 & 295 & 225 & 230 & 191 & 196 & 12 & 10 \\
\hline & & 278 & 204 & 232 & 336 & 255 & 229 & 16 & 8 \\
\hline & & 516 & 182 & 221 & 457 & 537 & 144 & 30 & 20 \\
\hline & & 382 & 284 & 286 & 285 & 220 & 191 & 17 & 2 \\
\hline & & 388 & 210 & 279 & 306 & 682 & 152 & 13 & 17 \\
\hline
\end{tabular}

\section{Specificity data}

Table S3. Specificity of C3Mannose, C7Mannose, C10Mannose, C7Xylose and C3GalNAc towards 4 bacterial species. E. coli BW25113, K. pneumoniae NCTC 09154, P. aeruginosa NCTC 10332 and S. saprophyticus NCTC 0792 were used.

1. E. coli

\begin{tabular}{|c|c|c|c|c|c|c|c|}
\hline \multirow[b]{2}{*}{ Species } & \multirow[b]{2}{*}{$\begin{array}{l}\text { Biological } \\
\text { replicate }\end{array}$} & \multirow[b]{2}{*}{$\begin{array}{l}\text { Technical } \\
\text { replicate }\end{array}$} & \multicolumn{5}{|c|}{ Total cluster size } \\
\hline & & & C7-Mannose & C3-Mannose & C10-Mannose & C3-GalNac & C7-Xylose \\
\hline \multirow{31}{*}{ E.coli } & \multirow{15}{*}{1} & \multirow{5}{*}{1} & 181 & 287 & 186 & 8 & 6 \\
\hline & & & 260 & 336 & 89 & 10 & 13 \\
\hline & & & 273 & 195 & 215 & 17 & 14 \\
\hline & & & 326 & 241 & 258 & 25 & 2 \\
\hline & & & 287 & 170 & 181 & 47 & 6 \\
\hline & & \multirow{5}{*}{2} & 168 & 185 & 96 & 14 & 13 \\
\hline & & & 255 & 164 & 82 & 21 & 14 \\
\hline & & & 251 & 109 & 98 & 29 & 58 \\
\hline & & & 321 & 166 & 146 & 23 & 45 \\
\hline & & & 308 & 292 & 170 & 24 & 19 \\
\hline & & \multirow{5}{*}{3} & 285 & 58 & 120 & 8 & 12 \\
\hline & & & 264 & 50 & 74 & 24 & 11 \\
\hline & & & 351 & 133 & 83 & 12 & 18 \\
\hline & & & 321 & 103 & 165 & 2 & 25 \\
\hline & & & 465 & 89 & 101 & 22 & 24 \\
\hline & \multirow{15}{*}{2} & \multirow{5}{*}{1} & 254 & 168 & 172 & 21 & 20 \\
\hline & & & 412 & 80 & 142 & 8 & 10 \\
\hline & & & 340 & 203 & 278 & 48 & 26 \\
\hline & & & 361 & 288 & 203 & 59 & 38 \\
\hline & & & 300 & 211 & 156 & 31 & 14 \\
\hline & & \multirow{5}{*}{2} & 249 & 140 & 51 & 8 & 8 \\
\hline & & & 379 & 140 & 352 & 12 & 7 \\
\hline & & & 483 & 154 & 180 & 15 & 36 \\
\hline & & & 520 & 95 & 105 & 0 & 0 \\
\hline & & & 232 & 168 & 116 & 24 & 16 \\
\hline & & \multirow{5}{*}{3} & 287 & 100 & 181 & 8 & 25 \\
\hline & & & 240 & 63 & 225 & 3 & 20 \\
\hline & & & 278 & 117 & 230 & 12 & 38 \\
\hline & & & 445 & 96 & 163 & 22 & 24 \\
\hline & & & 370 & 123 & 219 & 22 & 33 \\
\hline & 3 & 1 & 232 & 148 & 106 & 10 & 11 \\
\hline
\end{tabular}




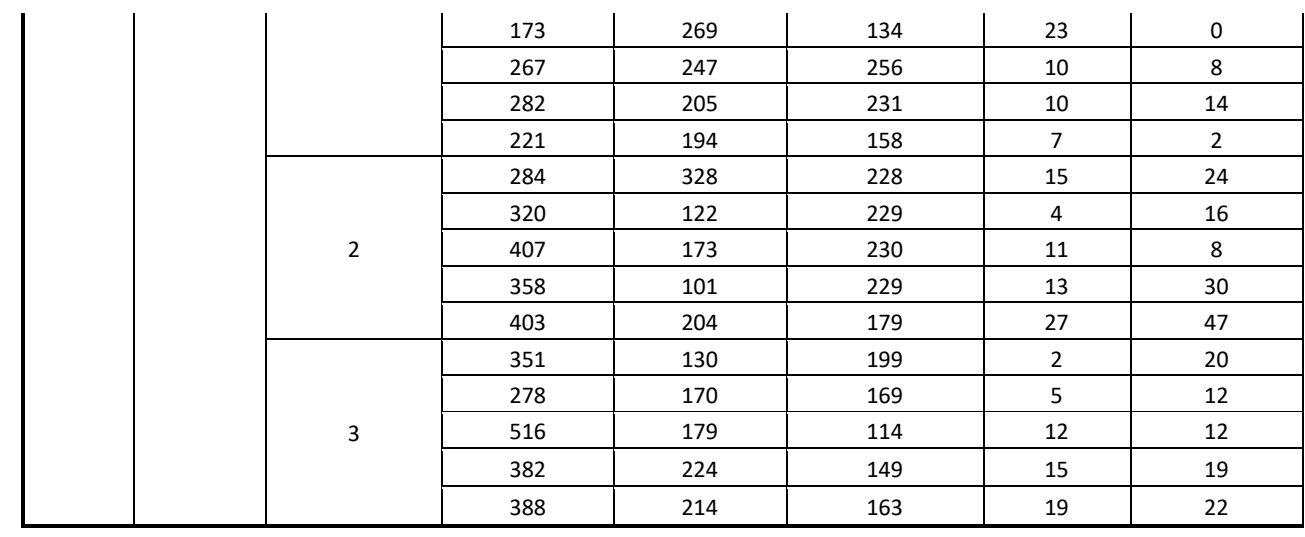

\section{K. pneumoniae}

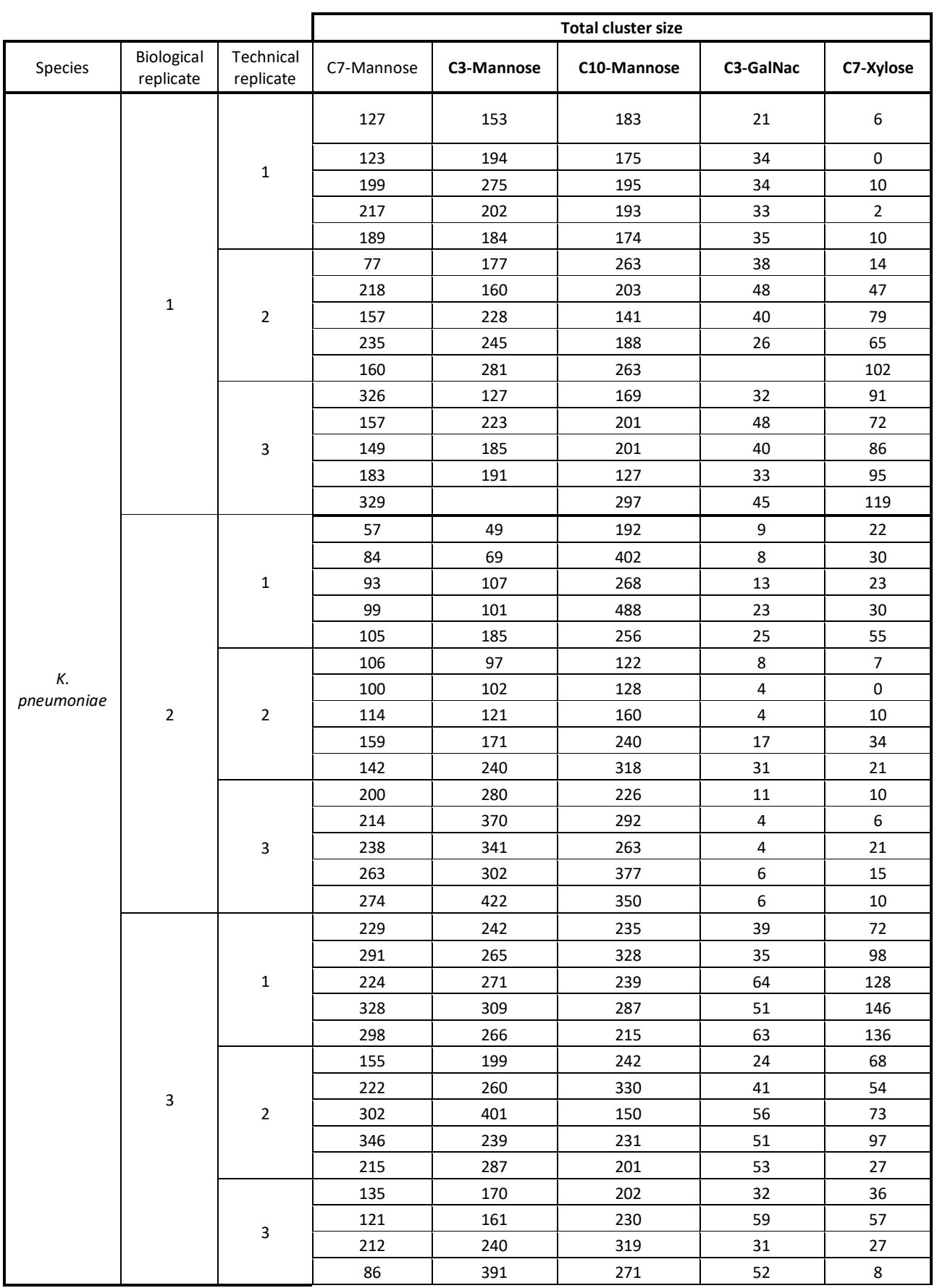




\section{P. aeruginosa}

\begin{tabular}{|c|c|c|c|c|c|c|c|}
\hline \multirow[b]{2}{*}{ Species } & \multirow[b]{2}{*}{$\begin{array}{l}\text { Biological } \\
\text { replicate }\end{array}$} & \multirow[b]{2}{*}{$\begin{array}{l}\text { Technical } \\
\text { replicate }\end{array}$} & \multicolumn{5}{|c|}{ Total cluster size } \\
\hline & & & C7-Mannose & C3-Mannose & C10-Mannose & C3-GalNac & C7-Xylose \\
\hline \multirow{45}{*}{$\begin{array}{c}P . \\
\text { aeruginosa }\end{array}$} & \multirow{15}{*}{1} & \multirow{5}{*}{1} & 119 & 68 & 93 & 49 & 181 \\
\hline & & & 100 & 88 & 151 & 117 & 80 \\
\hline & & & 91 & 72 & 256 & 96 & 111 \\
\hline & & & 90 & 82 & 277 & 141 & 130 \\
\hline & & & 113 & 114 & 233 & 217 & 103 \\
\hline & & \multirow{5}{*}{2} & 88 & 82 & 63 & 78 & 77 \\
\hline & & & 117 & 96 & 48 & 113 & 128 \\
\hline & & & 120 & 176 & 131 & 172 & 135 \\
\hline & & & 149 & 156 & 147 & 125 & 133 \\
\hline & & & 179 & 161 & 118 & 125 & 97 \\
\hline & & \multirow{5}{*}{3} & 53 & 65 & 50 & 44 & 63 \\
\hline & & & 94 & 83 & 91 & 87 & 106 \\
\hline & & & 84 & 92 & 64 & 58 & 120 \\
\hline & & & 151 & 88 & 55 & 171 & 68 \\
\hline & & & 100 & 113 & 99 & 116 & 64 \\
\hline & \multirow{15}{*}{2} & \multirow{5}{*}{1} & 345 & 155 & 163 & 121 & 214 \\
\hline & & & 392 & 228 & 220 & 44 & 126 \\
\hline & & & 307 & 241 & 250 & 92 & 258 \\
\hline & & & 343 & 175 & 257 & & 241 \\
\hline & & & 385 & 292 & 255 & & 124 \\
\hline & & \multirow{5}{*}{2} & 170 & 138 & 129 & 190 & 97 \\
\hline & & & 235 & 239 & 132 & 91 & 54 \\
\hline & & & 142 & 235 & 101 & 174 & 110 \\
\hline & & & 407 & 215 & 211 & 62 & 117 \\
\hline & & & 402 & 212 & 126 & 58 & 49 \\
\hline & & \multirow{5}{*}{3} & 106 & 74 & 137 & 93 & 192 \\
\hline & & & 126 & 92 & 341 & 86 & 230 \\
\hline & & & 99 & 139 & 209 & 148 & 165 \\
\hline & & & 72 & 126 & 245 & 112 & 186 \\
\hline & & & 107 & 158 & 277 & 191 & 287 \\
\hline & \multirow{15}{*}{3} & \multirow{5}{*}{1} & 71 & 69 & 199 & 88 & 134 \\
\hline & & & 112 & 93 & 169 & 78 & 103 \\
\hline & & & 176 & 112 & 114 & 84 & 80 \\
\hline & & & 228 & 133 & 149 & 203 & 78 \\
\hline & & & 239 & 103 & 163 & 151 & 207 \\
\hline & & \multirow{5}{*}{2} & 210 & 62 & 106 & 40 & 144 \\
\hline & & & 152 & 76 & 134 & 46 & 152 \\
\hline & & & 86 & 64 & 256 & 97 & 132 \\
\hline & & & 171 & 73 & 231 & 106 & 204 \\
\hline & & & 217 & 129 & 158 & 135 & 166 \\
\hline & & \multirow{5}{*}{3} & 73 & 34 & 228 & 6 & 95 \\
\hline & & & 136 & 50 & 229 & 11 & 59 \\
\hline & & & 91 & 55 & 230 & 16 & 57 \\
\hline & & & 113 & 67 & 229 & 18 & 62 \\
\hline & & & 115 & 79 & 179 & 20 & 99 \\
\hline
\end{tabular}

\section{S. saprophyticus}

\begin{tabular}{|c|c|c|c|c|c|c|c|}
\cline { 5 - 7 } Species & $\begin{array}{c}\text { Biological } \\
\text { replicate }\end{array}$ & $\begin{array}{c}\text { Technical } \\
\text { replicate }\end{array}$ & C7-Mannose & C3-Mannose & C10-Mannose & C3-GalNac & C7-Xylose \\
\hline
\end{tabular}




\begin{tabular}{|c|c|c|c|c|c|c|c|}
\hline \multirow{45}{*}{$\begin{array}{c}\text { S. } \\
\text { saprophyticus }\end{array}$} & \multirow{15}{*}{1} & \multirow{5}{*}{1} & 2 & 2 & 0 & 10 & 6 \\
\hline & & & 6 & 6 & 11 & 18 & 4 \\
\hline & & & 14 & 14 & 0 & 21 & 6 \\
\hline & & & 12 & 12 & 11 & 23 & 12 \\
\hline & & & 10 & 10 & 4 & 20 & 2 \\
\hline & & \multirow{5}{*}{2} & 18 & 18 & 8 & 10 & 28 \\
\hline & & & 14 & 14 & 12 & 16 & 38 \\
\hline & & & 8 & 8 & 43 & 20 & 17 \\
\hline & & & 8 & 8 & 2 & 13 & 32 \\
\hline & & & 4 & 4 & 12 & 20 & 18 \\
\hline & & \multirow{5}{*}{3} & 13 & 13 & 4 & 10 & 4 \\
\hline & & & 24 & 24 & 12 & 14 & 5 \\
\hline & & & 14 & 14 & 8 & 48 & 15 \\
\hline & & & 15 & 15 & 6 & 12 & 10 \\
\hline & & & 18 & 18 & 24 & 15 & 29 \\
\hline & \multirow{15}{*}{2} & \multirow{5}{*}{1} & 0 & 18 & 24 & 9 & 4 \\
\hline & & & 7 & 54 & 15 & 33 & 18 \\
\hline & & & 0 & 35 & 6 & 15 & 21 \\
\hline & & & 9 & 42 & 10 & 19 & 6 \\
\hline & & & 7 & 24 & 19 & 6 & 20 \\
\hline & & \multirow{5}{*}{2} & 6 & 6 & 10 & 0 & 0 \\
\hline & & & 10 & 2 & 16 & 6 & 4 \\
\hline & & & 18 & 0 & 14 & 18 & 11 \\
\hline & & & 0 & 8 & 18 & 6 & 8 \\
\hline & & & 43 & 10 & 15 & 17 & 8 \\
\hline & & \multirow{5}{*}{3} & 8 & 10 & 31 & 18 & 9 \\
\hline & & & 10 & 16 & 16 & 16 & 6 \\
\hline & & & 20 & 16 & 39 & 16 & 4 \\
\hline & & & 16 & 17 & 31 & 37 & 2 \\
\hline & & & 11 & 16 & 35 & 26 & 4 \\
\hline & \multirow{15}{*}{3} & \multirow{5}{*}{1} & 4 & 10 & 27 & 8 & 17 \\
\hline & & & 2 & 21 & 37 & 18 & 9 \\
\hline & & & 12 & 6 & 18 & 14 & 4 \\
\hline & & & 0 & 14 & 17 & 10 & 4 \\
\hline & & & 9 & 26 & 29 & 16 & 42 \\
\hline & & \multirow{5}{*}{2} & 6 & 15 & 11 & 2 & 0 \\
\hline & & & 21 & 22 & 11 & 8 & 9 \\
\hline & & & 12 & 16 & 9 & 4 & 12 \\
\hline & & & 23 & 18 & 13 & 4 & 16 \\
\hline & & & 6 & 46 & 6 & 8 & 14 \\
\hline & & \multirow{5}{*}{3} & 6 & 4 & 4 & 14 & 17 \\
\hline & & & 7 & 20 & 4 & 14 & 7 \\
\hline & & & 8 & 13 & 6 & 4 & 19 \\
\hline & & & 2 & 27 & 6 & 16 & 16 \\
\hline & & & 14 & 27 & 14 & 4 & 12 \\
\hline
\end{tabular}

\section{Agglutination assay in urine data}

Table S4. Agglutination assay in urine inoculated with E. coli BW25113 to a concentration of $10^{8}-10^{5} \mathrm{cfu} / \mathrm{ml}$ incubated with C7Mannose CuAAC (9).

\begin{tabular}{|c|c|c|c|c|c|c|c|}
\hline \multirow[b]{2}{*}{ Species } & \multirow[b]{2}{*}{$\begin{array}{c}10^{\mathrm{x}} \\
\mathrm{CFU} / \mathrm{ml}\end{array}$} & \multirow[b]{2}{*}{$\begin{array}{l}\text { Biological } \\
\text { replicate }\end{array}$} & \multirow[b]{2}{*}{$\begin{array}{l}\text { Technical } \\
\text { replicate }\end{array}$} & \multicolumn{4}{|c|}{ Total cluster size } \\
\hline & & & & $\begin{array}{l}\text { Unfiltered urine } \\
\text { (PBS probe) }\end{array}$ & $\begin{array}{l}\text { Unfiltered urine } \\
\text { (TSB probe) }\end{array}$ & $\begin{array}{c}0.2 \text { um filtered } \\
\text { urine } \\
\text { (PBS probe) }\end{array}$ & $\begin{array}{c}\text { E. coli in TSB (PBS } \\
\text { probe) }\end{array}$ \\
\hline \multirow{7}{*}{ E. coli } & \multirow{7}{*}{0} & \multirow{7}{*}{1} & \multirow{5}{*}{1} & 19 & 19 & 8 & 18 \\
\hline & & & & 89 & 22 & 20 & 20 \\
\hline & & & & 51 & 28 & 4 & 19 \\
\hline & & & & 88 & 28 & 23 & 10 \\
\hline & & & & 77 & 52 & 25 & 20 \\
\hline & & & \multirow{2}{*}{2} & 22 & 26 & 10 & 29 \\
\hline & & & & 62 & 47 & 10 & 33 \\
\hline
\end{tabular}




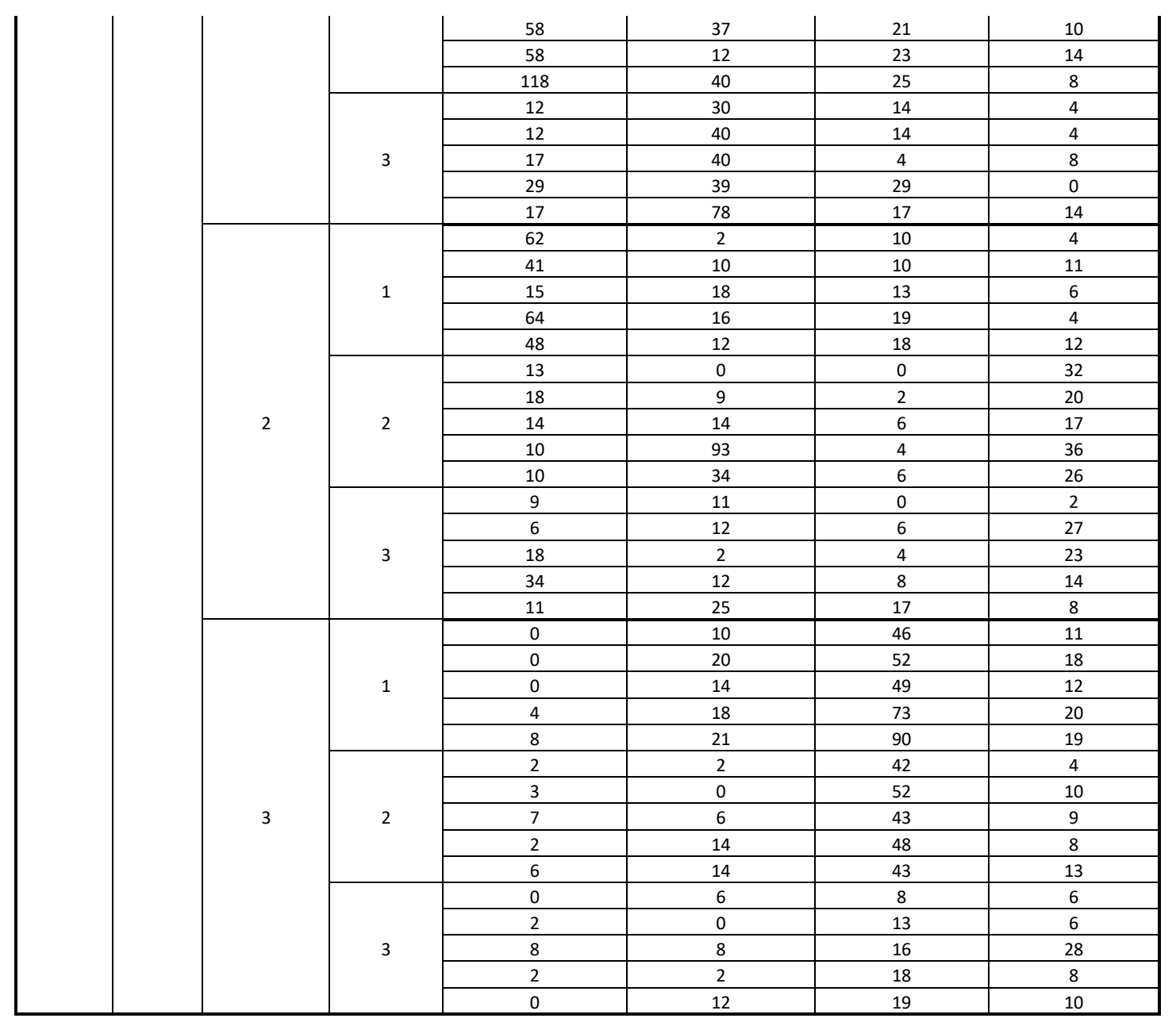

\begin{tabular}{|c|c|c|c|c|c|c|c|}
\hline \multirow[b]{2}{*}{ Species } & \multirow[b]{2}{*}{$\begin{array}{c}10^{\mathrm{x}} \\
\mathrm{CFU} / \mathrm{ml}\end{array}$} & \multirow[b]{2}{*}{$\begin{array}{l}\text { Biological } \\
\text { replicate }\end{array}$} & \multirow[b]{2}{*}{$\begin{array}{l}\text { Technical } \\
\text { replicate }\end{array}$} & \multicolumn{4}{|c|}{ Total cluster size } \\
\hline & & & & $\begin{array}{l}\text { Unfiltered urine } \\
\text { (PBS probe) }\end{array}$ & $\begin{array}{l}\text { Unfiltered urine } \\
\text { (TSB probe) }\end{array}$ & $\begin{array}{c}0.2 \text { um filtered } \\
\text { urine } \\
\text { (PBS probe) }\end{array}$ & $\begin{array}{c}\text { E. coli in TSB (PBS } \\
\text { probe) }\end{array}$ \\
\hline \multirow{25}{*}{ E.coli } & \multirow{25}{*}{5} & \multirow{15}{*}{1} & \multirow{5}{*}{1} & 28 & 35 & 6 & 75 \\
\hline & & & & 49 & 30 & 13 & 50 \\
\hline & & & & 89 & 56 & 27 & 64 \\
\hline & & & & 64 & 112 & 17 & 14 \\
\hline & & & & 53 & 71 & 32 & 18 \\
\hline & & & \multirow{5}{*}{2} & 52 & 31 & 37 & 17 \\
\hline & & & & 32 & 69 & 10 & 12 \\
\hline & & & & 57 & 55 & 13 & 20 \\
\hline & & & & 51 & 56 & 12 & 16 \\
\hline & & & & 113 & 74 & 48 & 19 \\
\hline & & & \multirow{5}{*}{3} & 75 & 43 & 19 & 18 \\
\hline & & & & 57 & 30 & 22 & 13 \\
\hline & & & & 95 & 73 & 26 & 24 \\
\hline & & & & 85 & 59 & 23 & 7 \\
\hline & & & & 94 & 75 & 31 & 10 \\
\hline & & \multirow{10}{*}{2} & \multirow{5}{*}{1} & 35 & 42 & 16 & 43 \\
\hline & & & & 71 & 39 & 7 & 23 \\
\hline & & & & 49 & 35 & 23 & 47 \\
\hline & & & & 76 & 32 & 29 & 42 \\
\hline & & & & 35 & 33 & 16 & 34 \\
\hline & & & \multirow{5}{*}{2} & 61 & 19 & 16 & 29 \\
\hline & & & & 72 & 12 & 58 & 33 \\
\hline & & & & 60 & 29 & 14 & 54 \\
\hline & & & & 102 & 33 & 11 & 33 \\
\hline & & & & 81 & 32 & 43 & 33 \\
\hline
\end{tabular}




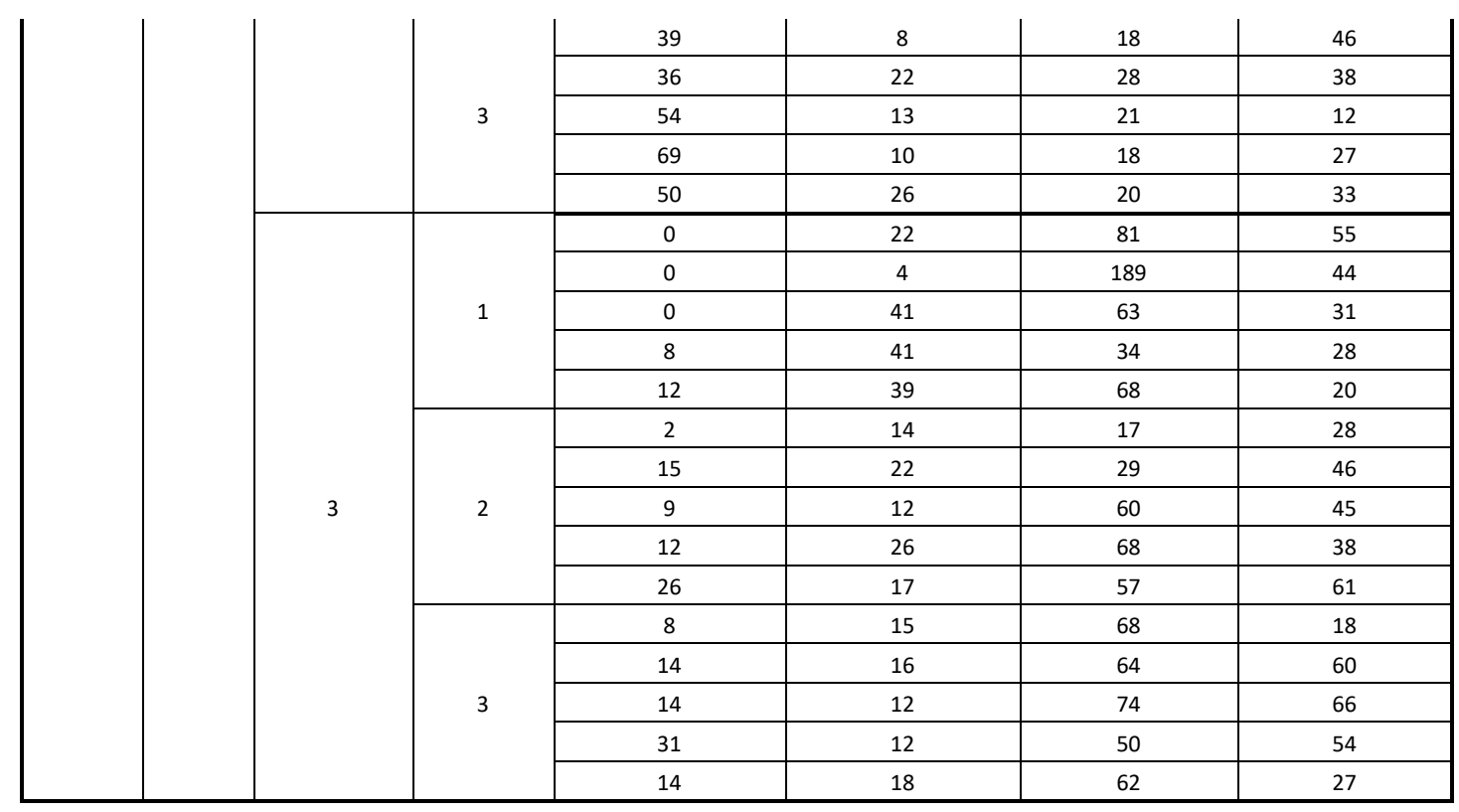

\begin{tabular}{|c|c|c|c|c|c|c|c|}
\hline \multirow[b]{2}{*}{ Species } & \multirow[b]{2}{*}{$\begin{array}{c}10^{\mathrm{x}} \\
\mathrm{CFU} / \mathrm{ml}\end{array}$} & \multirow[b]{2}{*}{$\begin{array}{l}\text { Biological } \\
\text { replicate }\end{array}$} & \multirow[b]{2}{*}{$\begin{array}{l}\text { Technical } \\
\text { replicate }\end{array}$} & \multicolumn{4}{|c|}{ Total cluster size } \\
\hline & & & & $\begin{array}{l}\text { Unfiltered urine } \\
\text { (PBS probe) }\end{array}$ & $\begin{array}{l}\text { Unfiltered urine } \\
\text { (TSB probe) }\end{array}$ & $\begin{array}{c}0.2 \text { um filtered } \\
\text { urine } \\
\text { (PBS probe) }\end{array}$ & $\begin{array}{c}\text { E. coli in TSB (PBS } \\
\text { probe) }\end{array}$ \\
\hline \multirow{33}{*}{ E.coli } & \multirow{33}{*}{6} & \multirow{15}{*}{1} & \multirow{5}{*}{1} & 52 & 64 & 29 & 82 \\
\hline & & & & 48 & 80 & 32 & 50 \\
\hline & & & & 26 & 99 & 56 & 54 \\
\hline & & & & 66 & 116 & 20 & 33 \\
\hline & & & & 42 & 127 & 45 & 71 \\
\hline & & & \multirow{5}{*}{2} & 44 & 70 & 32 & 61 \\
\hline & & & & 49 & 78 & 52 & 24 \\
\hline & & & & 74 & 91 & 48 & 29 \\
\hline & & & & 57 & 141 & 56 & 46 \\
\hline & & & & 52 & 95 & 77 & 31 \\
\hline & & & \multirow{5}{*}{3} & 63 & 33 & 8 & 47 \\
\hline & & & & 73 & 43 & 10 & 48 \\
\hline & & & & 74 & 47 & 15 & 28 \\
\hline & & & & 126 & 31 & 10 & 42 \\
\hline & & & & 148 & 33 & 16 & 28 \\
\hline & & \multirow{15}{*}{2} & \multirow{5}{*}{1} & 66 & 10 & 24 & 69 \\
\hline & & & & 61 & 12 & 32 & 26 \\
\hline & & & & 140 & 13 & 48 & 40 \\
\hline & & & & 61 & 21 & 40 & 57 \\
\hline & & & & 153 & 39 & 58 & 67 \\
\hline & & & \multirow{5}{*}{2} & 61 & 12 & 71 & 50 \\
\hline & & & & 66 & 40 & 24 & 81 \\
\hline & & & & 82 & 21 & 12 & 34 \\
\hline & & & & 38 & 32 & 32 & 69 \\
\hline & & & & 46 & 24 & 35 & 37 \\
\hline & & & \multirow{5}{*}{3} & 44 & 0 & 39 & 68 \\
\hline & & & & 63 & 10 & 94 & 89 \\
\hline & & & & 41 & 8 & 60 & 71 \\
\hline & & & & 95 & 16 & 19 & 77 \\
\hline & & & & 86 & 11 & 41 & 70 \\
\hline & & \multirow{3}{*}{3} & \multirow{3}{*}{1} & 9 & 8 & 50 & 41 \\
\hline & & & & 0 & 6 & 209 & 28 \\
\hline & & & & 4 & 103 & 87 & 44 \\
\hline
\end{tabular}




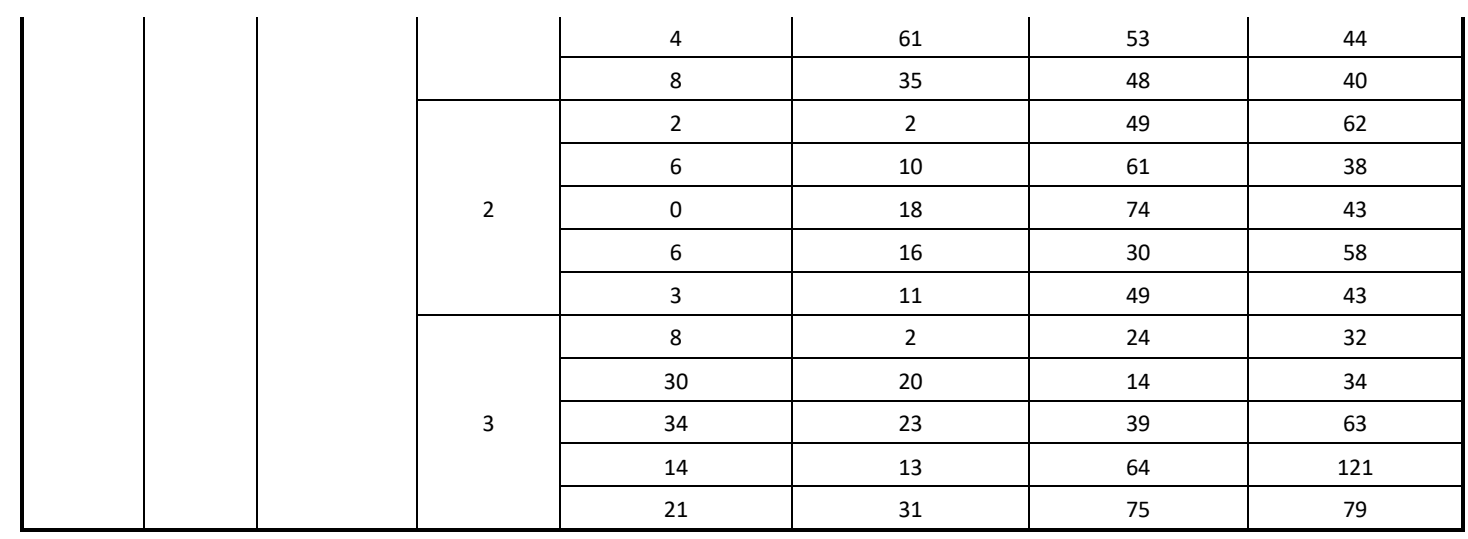

\begin{tabular}{|c|c|c|c|c|c|c|c|}
\hline \multirow[b]{2}{*}{ Species } & \multirow[b]{2}{*}{$\begin{array}{c}10^{x} \\
\mathrm{CFU} / \mathrm{ml}\end{array}$} & \multirow[b]{2}{*}{$\begin{array}{l}\text { Biological } \\
\text { replicate }\end{array}$} & \multirow[b]{2}{*}{$\begin{array}{l}\text { Technical } \\
\text { replicate }\end{array}$} & \multicolumn{4}{|c|}{ Total cluster size } \\
\hline & & & & $\begin{array}{l}\text { Unfiltered urine } \\
\text { (PBS probe) }\end{array}$ & $\begin{array}{l}\text { Unfiltered urine } \\
\text { (TSB probe) }\end{array}$ & $\begin{array}{c}0.2 \text { um filtered } \\
\text { urine } \\
\text { (PBS probe) }\end{array}$ & $\begin{array}{c}\text { E. coli in TSB (PBS } \\
\text { probe) }\end{array}$ \\
\hline \multirow{39}{*}{ E.coli } & \multirow{39}{*}{7} & \multirow{15}{*}{1} & \multirow{5}{*}{1} & 60 & 88 & 156 & 102 \\
\hline & & & & 52 & 94 & 218 & 109 \\
\hline & & & & 58 & 153 & 215 & 82 \\
\hline & & & & 103 & 67 & 136 & 133 \\
\hline & & & & 120 & 141 & 153 & 116 \\
\hline & & & \multirow{5}{*}{2} & 122 & 115 & 96 & 109 \\
\hline & & & & 147 & 179 & 80 & 120 \\
\hline & & & & 130 & 102 & 64 & 178 \\
\hline & & & & 173 & 105 & 89 & 157 \\
\hline & & & & 115 & 101 & 107 & 96 \\
\hline & & & \multirow{5}{*}{3} & & 57 & 88 & 164 \\
\hline & & & & & 90 & 80 & 229 \\
\hline & & & & & 180 & 103 & 164 \\
\hline & & & & & 106 & 147 & 133 \\
\hline & & & & & 109 & 130 & 177 \\
\hline & & \multirow{15}{*}{2} & \multirow{5}{*}{1} & 32 & 28 & 80 & 198 \\
\hline & & & & 53 & 67 & 105 & 251 \\
\hline & & & & 89 & 128 & 25 & 191 \\
\hline & & & & 69 & 146 & 52 & 260 \\
\hline & & & & 77 & 134 & 81 & 283 \\
\hline & & & \multirow{5}{*}{2} & 46 & 26 & 165 & 131 \\
\hline & & & & 31 & 22 & 144 & 169 \\
\hline & & & & 46 & 41 & 72 & 216 \\
\hline & & & & 57 & 81 & 221 & 146 \\
\hline & & & & 35 & 57 & 245 & 202 \\
\hline & & & \multirow{5}{*}{3} & 61 & 26 & 72 & 284 \\
\hline & & & & 54 & 41 & 101 & 327 \\
\hline & & & & 75 & 28 & 68 & 490 \\
\hline & & & & 49 & 48 & 121 & 324 \\
\hline & & & & 101 & 75 & 142 & 381 \\
\hline & & \multirow{9}{*}{3} & \multirow{5}{*}{1} & 11 & 27 & 160 & 74 \\
\hline & & & & 4 & 42 & 83 & 68 \\
\hline & & & & 17 & 55 & 213 & 74 \\
\hline & & & & 12 & 48 & 127 & 115 \\
\hline & & & & 27 & 85 & 154 & 95 \\
\hline & & & \multirow{4}{*}{2} & 4 & 14 & 195 & 68 \\
\hline & & & & 4 & 31 & 117 & 93 \\
\hline & & & & 12 & 31 & 144 & 137 \\
\hline & & & & 19 & 34 & 159 & 220 \\
\hline
\end{tabular}




\begin{tabular}{|c|c|c|c|c|c|c|}
\hline \multirow{3}{*}{} & & 11 & 60 & 143 & 200 \\
\cline { 2 - 6 } & \multirow{4}{*}{3} & 0 & 42 & 36 & 327 \\
\cline { 3 - 6 } & \multirow{3}{*}{3} & 10 & 76 & 75 & 97 \\
\cline { 3 - 6 } & & 10 & 127 & 103 & 330 \\
\cline { 3 - 6 } & & 6 & 47 & 131 & 151 \\
\hline & & 8 & 80 & 165 & 251 \\
\hline
\end{tabular}

\begin{tabular}{|c|c|c|c|c|c|c|c|}
\hline \multirow[b]{2}{*}{ Species } & \multirow[b]{2}{*}{$\begin{array}{c}10^{x} \\
\mathrm{CFU} / \mathrm{ml}\end{array}$} & \multirow[b]{2}{*}{$\begin{array}{l}\text { Biological } \\
\text { replicate }\end{array}$} & \multirow[b]{2}{*}{$\begin{array}{l}\text { Technical } \\
\text { replicate }\end{array}$} & \multicolumn{4}{|c|}{ Total cluster size } \\
\hline & & & & $\begin{array}{l}\text { Unfiltered urine } \\
\text { (PBS probe) }\end{array}$ & $\begin{array}{l}\text { Unfiltered urine } \\
\text { (TSB probe) }\end{array}$ & $\begin{array}{c}0.2 \text { um filtered } \\
\text { urine } \\
\text { (PBS probe) }\end{array}$ & $\begin{array}{c}\text { E. coli in TSB (PBS } \\
\text { probe) }\end{array}$ \\
\hline \multirow{44}{*}{ E.coli } & \multirow{44}{*}{8} & \multirow{15}{*}{1} & \multirow{5}{*}{1} & 143 & 234 & 219 & 292 \\
\hline & & & & 111 & 199 & 210 & 404 \\
\hline & & & & 93 & 393 & 266 & 587 \\
\hline & & & & 93 & 331 & 314 & 402 \\
\hline & & & & 84 & 428 & 303 & 642 \\
\hline & & & \multirow{5}{*}{2} & 181 & 238 & 251 & 305 \\
\hline & & & & 168 & 330 & 272 & 311 \\
\hline & & & & 207 & 273 & 310 & 396 \\
\hline & & & & 171 & 291 & 282 & 342 \\
\hline & & & & 273 & 415 & 354 & 251 \\
\hline & & & \multirow{5}{*}{3} & 32 & 331 & 155 & 191 \\
\hline & & & & 49 & 246 & 121 & 284 \\
\hline & & & & 55 & 295 & 150 & 499 \\
\hline & & & & 82 & 269 & 192 & 493 \\
\hline & & & & 62 & 311 & 190 & 259 \\
\hline & & \multirow{15}{*}{2} & \multirow{5}{*}{1} & 79 & 89 & 180 & 280 \\
\hline & & & & 82 & 127 & 98 & 390 \\
\hline & & & & 107 & 126 & 112 & 439 \\
\hline & & & & 41 & 220 & 206 & 402 \\
\hline & & & & 73 & 152 & 187 & 496 \\
\hline & & & \multirow{5}{*}{2} & 83 & 148 & 107 & 265 \\
\hline & & & & 123 & 159 & 157 & 397 \\
\hline & & & & 131 & 175 & 134 & 481 \\
\hline & & & & 140 & 164 & 199 & 595 \\
\hline & & & & 83 & 317 & 192 & 449 \\
\hline & & & \multirow{5}{*}{3} & 35 & 91 & 135 & 208 \\
\hline & & & & 51 & 86 & 162 & 332 \\
\hline & & & & 31 & 93 & 165 & 297 \\
\hline & & & & 39 & 124 & 184 & 341 \\
\hline & & & & 75 & 137 & 197 & 258 \\
\hline & & \multirow{14}{*}{3} & \multirow{5}{*}{1} & 30 & 134 & 81 & 225 \\
\hline & & & & 29 & 245 & 116 & 269 \\
\hline & & & & 34 & 354 & 133 & 207 \\
\hline & & & & 43 & 161 & 143 & 228 \\
\hline & & & & 28 & 148 & 171 & 226 \\
\hline & & & \multirow{5}{*}{2} & 6 & 34 & 60 & 365 \\
\hline & & & & 10 & 77 & 79 & 458 \\
\hline & & & & 10 & 91 & 106 & 238 \\
\hline & & & & 20 & 159 & 73 & 392 \\
\hline & & & & 21 & 332 & 88 & 448 \\
\hline & & & \multirow{4}{*}{3} & 4 & 43 & 100 & 239 \\
\hline & & & & 20 & 38 & 164 & 400 \\
\hline & & & & 22 & 43 & 259 & 341 \\
\hline & & & & 16 & 38 & 205 & 371 \\
\hline
\end{tabular}




\section{Optimisation by sample concentration data}

Table S5. A TCS comparison between $10^{3}$ to $10^{8} \mathrm{cfu} / \mathrm{ml}$ E. coli BW25113 and TSB blank samples incubated with C7-Mannose conjugated $10 \mu \mathrm{m}$ latex microspheres in unconcentrated (blue) and 100x concentrated (orange) samples.

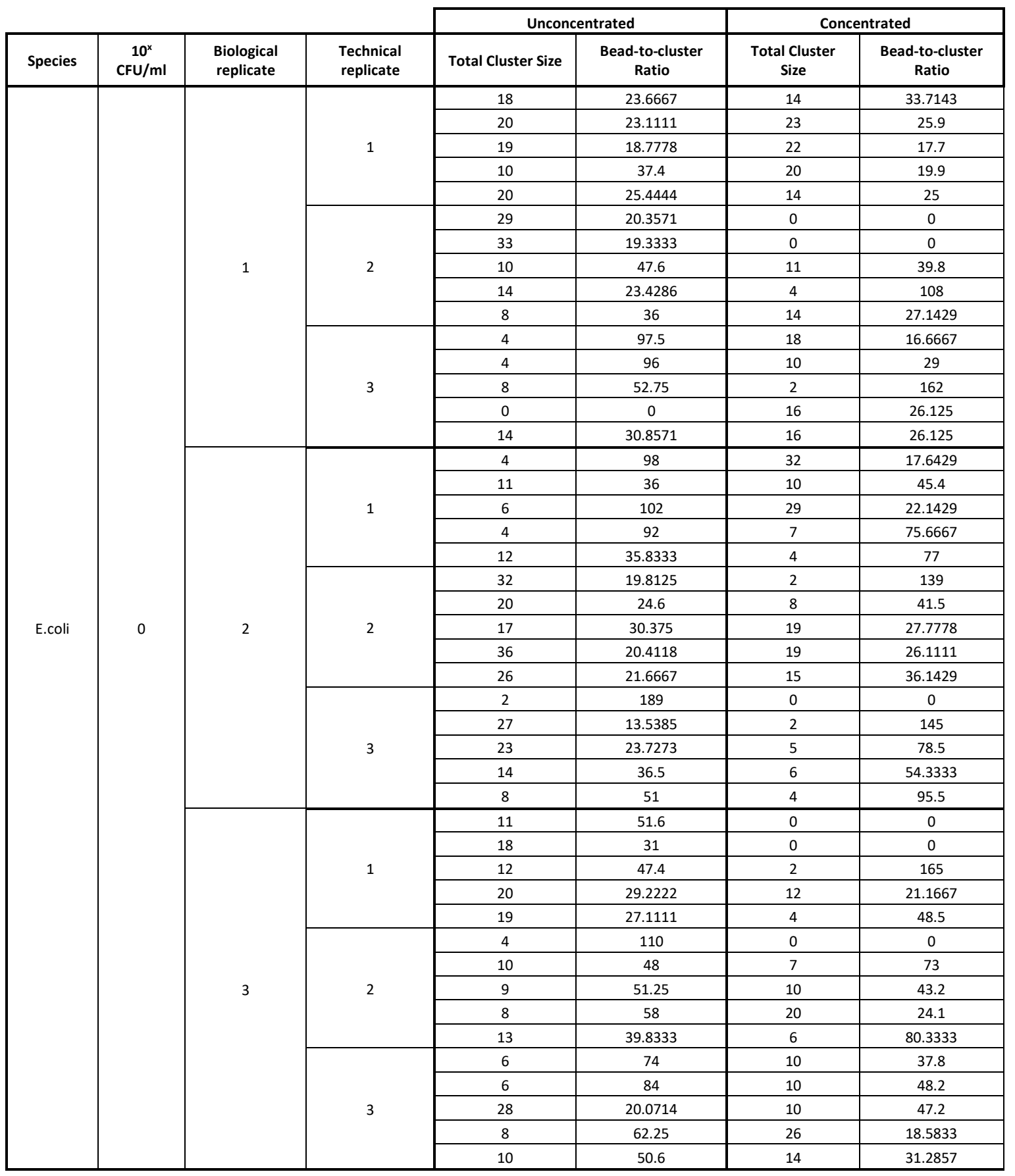




\begin{tabular}{|c|c|c|c|c|c|c|c|}
\hline \multirow[b]{2}{*}{ Species } & \multirow[b]{2}{*}{$\begin{array}{c}10^{\mathrm{x}} \\
\mathrm{CFU} / \mathrm{ml}\end{array}$} & \multirow[b]{2}{*}{$\begin{array}{l}\text { Biological } \\
\text { replicate }\end{array}$} & \multirow[b]{2}{*}{$\begin{array}{l}\text { Technical } \\
\text { replicate }\end{array}$} & \multicolumn{2}{|c|}{ Unconcentrated } & \multicolumn{2}{|c|}{ Concentrated } \\
\hline & & & & Total Cluster Size & $\begin{array}{c}\text { Bead-to-cluster } \\
\text { Ratio }\end{array}$ & $\begin{array}{c}\text { Total Cluster } \\
\text { Size }\end{array}$ & $\begin{array}{l}\text { Bead-to-cluster } \\
\text { Ratio }\end{array}$ \\
\hline \multirow{45}{*}{ E.coli } & \multirow{45}{*}{3} & \multirow{15}{*}{1} & \multirow{5}{*}{1} & 10 & 51 & 10 & 43 \\
\hline & & & & 2 & 173 & 10 & 34.4 \\
\hline & & & & 6 & 59.6667 & 10 & 44.6 \\
\hline & & & & 19 & 27.1111 & 12 & 33.8333 \\
\hline & & & & 16 & 29.25 & 20 & 25.3333 \\
\hline & & & \multirow{5}{*}{2} & 14 & 30.4286 & 18 & 26.8889 \\
\hline & & & & 7 & 71.6667 & 8 & 71.3333 \\
\hline & & & & 11 & 47.2 & 47 & 13.4348 \\
\hline & & & & 23 & 25.4 & 47 & 11.1739 \\
\hline & & & & 16 & 34.4286 & 38 & 13.5556 \\
\hline & & & \multirow{5}{*}{3} & 8 & 43 & 14 & 33 \\
\hline & & & & 4 & 75 & 25 & 23.7273 \\
\hline & & & & 16 & 30.5 & 20 & 21.3 \\
\hline & & & & 6 & 70.3333 & 53 & 10.5833 \\
\hline & & & & 12 & 37 & 10 & 41.8 \\
\hline & & \multirow{15}{*}{2} & \multirow{5}{*}{1} & 2 & 185 & 13 & 38.6 \\
\hline & & & & 4 & 101.5 & 8 & 58 \\
\hline & & & & 12 & 33.6667 & 23 & 25.4545 \\
\hline & & & & 17 & 27.375 & 32 & 15.4375 \\
\hline & & & & 12 & 38.8333 & 23 & 22.8182 \\
\hline & & & \multirow{5}{*}{2} & 4 & 87 & 9 & 61.75 \\
\hline & & & & 10 & 43.4 & 54 & 14.5833 \\
\hline & & & & 18 & 25.2222 & 31 & 21.4 \\
\hline & & & & 3 & 172 & 67 & 14.8125 \\
\hline & & & & 10 & 38.8 & 105 & 10.0426 \\
\hline & & & \multirow{5}{*}{3} & 2 & 193 & 27 & 25.4615 \\
\hline & & & & 6 & 74.6667 & 35 & 23.6471 \\
\hline & & & & 8 & 59.25 & 52 & 17.3478 \\
\hline & & & & 11 & 43.8 & 41 & 17.85 \\
\hline & & & & 17 & 29.2857 & 66 & 13.4194 \\
\hline & & \multirow{15}{*}{3} & \multirow{5}{*}{1} & 10 & 55 & 18 & 25.7778 \\
\hline & & & & 6 & 61.3333 & 27 & 24.3333 \\
\hline & & & & 18 & 30.3333 & 10 & 56 \\
\hline & & & & 4 & 110.5 & 21 & 27.2222 \\
\hline & & & & 16 & 32.8571 & 10 & 67.75 \\
\hline & & & \multirow{5}{*}{2} & 6 & 64.3333 & 40 & 16.3333 \\
\hline & & & & 19 & 28.7778 & 13 & 46.6667 \\
\hline & & & & 16 & 29.5 & 29 & 19.5 \\
\hline & & & & 10 & 49.6 & 30 & 22.2143 \\
\hline & & & & 6 & 90 & 30 & 19.4667 \\
\hline & & & \multirow{5}{*}{3} & 9 & 73.25 & 41 & 13.3158 \\
\hline & & & & 23 & 21.9091 & 34 & 21.8824 \\
\hline & & & & 16 & 33.75 & 12 & 50.1667 \\
\hline & & & & 10 & 51.8 & 36 & 22.2353 \\
\hline & & & & 12 & 50.3333 & 64 & 13.5172 \\
\hline
\end{tabular}




\begin{tabular}{|c|c|c|c|c|c|c|c|}
\hline \multirow[b]{2}{*}{ Species } & \multirow[b]{2}{*}{$\begin{array}{c}10^{\mathrm{x}} \\
\mathrm{CFU} / \mathrm{ml}\end{array}$} & \multirow[b]{2}{*}{$\begin{array}{l}\text { Biological } \\
\text { replicate }\end{array}$} & \multirow[b]{2}{*}{$\begin{array}{l}\text { Technical } \\
\text { replicate }\end{array}$} & \multicolumn{2}{|c|}{ Unconcentrated } & \multicolumn{2}{|c|}{ Concentrated } \\
\hline & & & & Total Cluster Size & $\begin{array}{c}\text { Bead-to-cluster } \\
\text { Ratio }\end{array}$ & $\begin{array}{c}\text { Total Cluster } \\
\text { Size }\end{array}$ & $\begin{array}{c}\text { Bead-to-cluster } \\
\text { Ratio }\end{array}$ \\
\hline \multirow{45}{*}{ E.coli } & \multirow{45}{*}{4} & \multirow{15}{*}{1} & \multirow{5}{*}{1} & 4 & 74.5 & 13 & 45.8 \\
\hline & & & & 8 & 49.6667 & 26 & 17.6923 \\
\hline & & & & 8 & 37.5 & 24 & 24.0909 \\
\hline & & & & 6 & 53 & 15 & 40.1429 \\
\hline & & & & 14 & 28.5714 & 36 & 17.8889 \\
\hline & & & \multirow{5}{*}{2} & 6 & 43.3333 & 13 & 31.8333 \\
\hline & & & & 16 & 16.875 & 53 & 12.6 \\
\hline & & & & 25 & 18.4167 & 39 & 12.3684 \\
\hline & & & & 14 & 24.2857 & 77 & 8.3611 \\
\hline & & & & 21 & 17.6 & 25 & 20.25 \\
\hline & & & \multirow{5}{*}{3} & 17 & 24.25 & 36 & 15.6 \\
\hline & & & & 14 & 21.1429 & 16 & 33 \\
\hline & & & & 11 & 31.8 & 32 & 17.8 \\
\hline & & & & 10 & 34.8 & 30 & 21.8 \\
\hline & & & & 12 & 29.1667 & 88 & 9.6 \\
\hline & & \multirow{15}{*}{2} & \multirow{5}{*}{1} & 4 & 64 & 12 & 30.5 \\
\hline & & & & 9 & 38.75 & 23 & 26.9 \\
\hline & & & & 14 & 25 & 24 & 22.5833 \\
\hline & & & & 6 & 75.6667 & 18 & 34.625 \\
\hline & & & & 5 & 95.5 & 31 & 17.2667 \\
\hline & & & \multirow{5}{*}{2} & 2 & 131 & 27 & 26.9167 \\
\hline & & & & 0 & 0 & 29 & 16.5 \\
\hline & & & & 6 & 51.3333 & 22 & 25 \\
\hline & & & & 2 & 111 & 34 & 16.7857 \\
\hline & & & & 8 & 37.5 & 52 & 13.08 \\
\hline & & & \multirow{5}{*}{3} & 2 & 114 & 54 & 14.64 \\
\hline & & & & 8 & 41.75 & 18 & 30.3333 \\
\hline & & & & 2 & 186 & 29 & 19.0714 \\
\hline & & & & 7 & 47.6667 & 79 & 11 \\
\hline & & & & 4 & 79 & 37 & 18.4118 \\
\hline & & \multirow{15}{*}{3} & \multirow{5}{*}{1} & 22 & 23.7 & 33 & 14.8667 \\
\hline & & & & 14 & 38.8571 & 29 & 21.0769 \\
\hline & & & & 8 & 57.25 & 45 & 15.2857 \\
\hline & & & & 18 & 30.7778 & 41 & 16.25 \\
\hline & & & & 23 & 24.2727 & 28 & 20.8462 \\
\hline & & & \multirow{5}{*}{2} & 12 & 36.6 & 25 & 20 \\
\hline & & & & 6 & 65.6667 & 21 & 23.4 \\
\hline & & & & 2 & 165 & 14 & 31.4286 \\
\hline & & & & 15 & 35.5714 & 14 & 33.7143 \\
\hline & & & & 16 & 33.5 & 18 & 20.4444 \\
\hline & & & \multirow{5}{*}{3} & 14 & 30.2857 & 27 & 16.6923 \\
\hline & & & & 2 & 206 & 29 & 16.8571 \\
\hline & & & & 12 & 36.2 & 36 & 17.8235 \\
\hline & & & & 0 & 0 & 70 & 10.4062 \\
\hline & & & & 13 & 21.5 & 33 & 21.1333 \\
\hline
\end{tabular}




\begin{tabular}{|c|c|c|c|c|c|c|c|}
\hline \multirow[b]{2}{*}{ Species } & \multirow[b]{2}{*}{$\begin{array}{c}10^{\mathrm{x}} \\
\mathrm{CFU} / \mathrm{ml}\end{array}$} & \multirow[b]{2}{*}{$\begin{array}{l}\text { Biological } \\
\text { replicate }\end{array}$} & \multirow[b]{2}{*}{$\begin{array}{l}\text { Technical } \\
\text { replicate }\end{array}$} & \multicolumn{2}{|c|}{ Unconcentrated } & \multicolumn{2}{|c|}{ Concentrated } \\
\hline & & & & Total Cluster Size & $\begin{array}{c}\text { Bead-to-cluster } \\
\text { Ratio }\end{array}$ & $\begin{array}{l}\text { Total Cluster } \\
\text { Size }\end{array}$ & $\begin{array}{l}\text { Bead-to-cluster } \\
\text { Ratio }\end{array}$ \\
\hline \multirow{45}{*}{ E.coli } & \multirow{45}{*}{5} & \multirow{15}{*}{1} & \multirow{5}{*}{1} & 75 & 12.3438 & 117 & 5.04 \\
\hline & & & & 50 & 15.7083 & 44 & 11.2 \\
\hline & & & & 64 & 12.08 & 66 & 7.6071 \\
\hline & & & & 14 & 31.2857 & 10 & 29.2 \\
\hline & & & & 18 & 25.5556 & 56 & 5.2308 \\
\hline & & & \multirow{5}{*}{2} & 17 & 29.75 & 168 & 4.375 \\
\hline & & & & 12 & 26.3333 & 120 & 5.6909 \\
\hline & & & & 20 & 24.3 & 70 & 7.7742 \\
\hline & & & & 16 & 23.25 & 72 & 9.1379 \\
\hline & & & & 19 & 22.7778 & 213 & 4.4471 \\
\hline & & & \multirow{5}{*}{3} & 18 & 27.6667 & 104 & 7.6 \\
\hline & & & & 13 & 28.1667 & 117 & 8.551 \\
\hline & & & & 24 & 17.3333 & 42 & 11.4444 \\
\hline & & & & 7 & 63.3333 & 58 & 9.5833 \\
\hline & & & & 10 & 44.2 & 88 & 6.7105 \\
\hline & & \multirow{15}{*}{2} & \multirow{5}{*}{1} & 43 & 15.85 & 132 & 7.3509 \\
\hline & & & & 23 & 23.8889 & 110 & 5.5106 \\
\hline & & & & 47 & 12.4783 & 64 & 11.087 \\
\hline & & & & 42 & 14.6 & 77 & 7.4688 \\
\hline & & & & 34 & 18.1765 & 84 & 7.9429 \\
\hline & & & \multirow{5}{*}{2} & 29 & 17.9286 & 46 & 13.4737 \\
\hline & & & & 33 & 19.9375 & 52 & 11.5417 \\
\hline & & & & 54 & 13.72 & 61 & 10.7407 \\
\hline & & & & 33 & 16.8 & 51 & 8.7083 \\
\hline & & & & 33 & 17.9333 & 60 & 9.3077 \\
\hline & & & \multirow{5}{*}{3} & 46 & 14.0455 & 65 & 5.2143 \\
\hline & & & & 38 & 17.5 & 95 & 3.5 \\
\hline & & & & 12 & 35 & 82 & 5.7941 \\
\hline & & & & 27 & 24.6154 & 111 & 3.6087 \\
\hline & & & & 33 & 17.5 & 154 & 4.2258 \\
\hline & & \multirow{15}{*}{3} & \multirow{5}{*}{1} & 55 & 14.68 & 62 & 12.1034 \\
\hline & & & & 44 & 13.4286 & 75 & 9.9412 \\
\hline & & & & 31 & 18.3333 & 88 & 7.7895 \\
\hline & & & & 28 & 19.5 & 85 & 9.3421 \\
\hline & & & & 20 & 29.4444 & 110 & 7.3529 \\
\hline & & & \multirow{5}{*}{2} & 28 & 24 & 28 & 13.2308 \\
\hline & & & & 46 & 15.8095 & 37 & 7.7059 \\
\hline & & & & 45 & 16.9 & 33 & 10.9333 \\
\hline & & & & 38 & 19.8235 & 33 & 14.8 \\
\hline & & & & 61 & 13.7407 & 37 & 12.6875 \\
\hline & & & \multirow{5}{*}{3} & 18 & 34.75 & 41 & 8.5 \\
\hline & & & & 60 & 15 & 29 & 11.8462 \\
\hline & & & & 66 & 14.1852 & 34 & 8.1333 \\
\hline & & & & 54 & 13.3462 & 39 & 9.2778 \\
\hline & & & & 27 & 32.3636 & 39 & 8.4706 \\
\hline
\end{tabular}




\begin{tabular}{|c|c|c|c|c|c|c|c|}
\hline \multirow[b]{2}{*}{ Species } & \multirow[b]{2}{*}{$\begin{array}{c}10^{\mathrm{x}} \\
\mathrm{CFU} / \mathrm{ml}\end{array}$} & \multirow[b]{2}{*}{$\begin{array}{l}\text { Biological } \\
\text { replicate }\end{array}$} & \multirow[b]{2}{*}{$\begin{array}{l}\text { Technical } \\
\text { replicate }\end{array}$} & \multicolumn{2}{|c|}{ Unconcentrated } & \multicolumn{2}{|c|}{ Concentrated } \\
\hline & & & & Total Cluster Size & $\begin{array}{c}\text { Bead-to-cluster } \\
\text { Ratio }\end{array}$ & $\begin{array}{l}\text { Total Cluster } \\
\text { Size }\end{array}$ & $\begin{array}{c}\text { Bead-to-cluster } \\
\text { Ratio }\end{array}$ \\
\hline \multirow{33}{*}{ E.coli } & \multirow{33}{*}{6} & \multirow{9}{*}{1} & \multirow{3}{*}{1} & 50 & 13.4211 & 135 & 1.2381 \\
\hline & & & & 54 & 9.7308 & 148 & 1.1731 \\
\hline & & & & 33 & 17.2 & 205 & 0.7077 \\
\hline & & & \multirow{5}{*}{2} & 61 & 8.4138 & 199 & 1.0161 \\
\hline & & & & 24 & 15 & 303 & 0.8902 \\
\hline & & & & 29 & 11 & 261 & 1.1127 \\
\hline & & & & 46 & 11.8333 & 255 & 0.6727 \\
\hline & & & & 31 & 12.3571 & 137 & 1.7273 \\
\hline & & & 3 & 28 & 15.5 & 147 & 1.5946 \\
\hline & & \multirow{9}{*}{2} & \multirow{5}{*}{1} & 69 & 9.8 & 122 & 3.8485 \\
\hline & & & & 26 & 17.4167 & 162 & 3 \\
\hline & & & & 40 & 15.7778 & 163 & 2.4074 \\
\hline & & & & 57 & 11.12 & 274 & 1.8111 \\
\hline & & & & 67 & 9.1429 & 289 & 1.6588 \\
\hline & & & \multirow{4}{*}{2} & 50 & 8.8261 & 350 & 1.1333 \\
\hline & & & & 81 & 6 & 277 & 1.5444 \\
\hline & & & & 34 & 9.6429 & 340 & 1.1376 \\
\hline & & & & 69 & 5.2121 & 345 & 1.0093 \\
\hline & & \multirow{15}{*}{3} & \multirow{5}{*}{1} & 41 & 14.85 & 188 & 4.5455 \\
\hline & & & & 28 & 20.6667 & 183 & 4.537 \\
\hline & & & & 44 & 13.7143 & 262 & 3.2877 \\
\hline & & & & 44 & 11.2381 & 308 & 2.8229 \\
\hline & & & & 40 & 13.2353 & 240 & 3.1279 \\
\hline & & & \multirow{5}{*}{2} & 62 & 9.5185 & 216 & 2.5 \\
\hline & & & & 38 & 15.1765 & 247 & 2.5833 \\
\hline & & & & 43 & 13.0526 & 234 & 1.3239 \\
\hline & & & & 58 & 10.1852 & 372 & 2.1316 \\
\hline & & & & 43 & 16.9375 & 248 & 2.2727 \\
\hline & & & \multirow{5}{*}{3} & 32 & 12.2143 & 106 & 4.3158 \\
\hline & & & & 34 & 15.6875 & 104 & 4.9706 \\
\hline & & & & 63 & 9.3448 & 140 & 3.3864 \\
\hline & & & & 121 & 6.6226 & 176 & 2.6727 \\
\hline & & & & 79 & 8.8611 & 199 & 2.5538 \\
\hline
\end{tabular}




\begin{tabular}{|c|c|c|c|c|c|c|c|}
\hline \multirow[b]{2}{*}{ Species } & \multirow[b]{2}{*}{$\begin{array}{c}10^{\mathrm{x}} \\
\mathrm{CFU} / \mathrm{ml}\end{array}$} & \multirow[b]{2}{*}{$\begin{array}{l}\text { Biological } \\
\text { replicate }\end{array}$} & \multirow[b]{2}{*}{$\begin{array}{l}\text { Technical } \\
\text { replicate }\end{array}$} & \multicolumn{2}{|c|}{ Unconcentrated } & \multicolumn{2}{|c|}{ Concentrated } \\
\hline & & & & Total Cluster Size & $\begin{array}{c}\text { Bead-to-cluster } \\
\text { Ratio }\end{array}$ & $\begin{array}{l}\text { Total Cluster } \\
\text { Size }\end{array}$ & $\begin{array}{l}\text { Bead-to-cluster } \\
\text { Ratio }\end{array}$ \\
\hline \multirow{45}{*}{ E.coli } & \multirow{45}{*}{7} & \multirow{15}{*}{1} & \multirow{5}{*}{1} & 102 & 0.961 & 886 & 0.9179 \\
\hline & & & & 109 & 0.74 & 388 & 1.76 \\
\hline & & & & 82 & 0.8553 & 428 & 2.1124 \\
\hline & & & & 133 & 0.7273 & 473 & 1.1858 \\
\hline & & & & 116 & 0.8052 & 387 & 1.6628 \\
\hline & & & \multirow{5}{*}{2} & 109 & 0.759 & 578 & 1.2394 \\
\hline & & & & 120 & 0.8228 & 538 & 1.0385 \\
\hline & & & & 178 & 0.6778 & 398 & 1.25 \\
\hline & & & & 157 & 0.5667 & 413 & 1.8049 \\
\hline & & & & 96 & 1.4923 & 500 & 2.0569 \\
\hline & & & \multirow{5}{*}{3} & 164 & 1.3438 & 386 & 1.8824 \\
\hline & & & & 229 & 1.2152 & 725 & 1.5 \\
\hline & & & & 164 & 0.7986 & 407 & 1.8224 \\
\hline & & & & 133 & 0.8676 & 536 & 1.8492 \\
\hline & & & & 177 & 0.8406 & 374 & 2.0091 \\
\hline & & \multirow{15}{*}{2} & \multirow{5}{*}{1} & 198 & 4.2381 & 886 & 0.9179 \\
\hline & & & & 251 & 2.65 & 388 & 1.76 \\
\hline & & & & 191 & 2.8033 & 428 & 2.1124 \\
\hline & & & & 260 & 2.3418 & 473 & 1.1858 \\
\hline & & & & 283 & 2.5918 & 387 & 1.6628 \\
\hline & & & \multirow{5}{*}{2} & 131 & 3.4872 & 578 & 1.2394 \\
\hline & & & & 169 & 2.1071 & 538 & 1.0385 \\
\hline & & & & 216 & 1.7612 & 398 & 1.25 \\
\hline & & & & 146 & 2.2292 & 413 & 1.8049 \\
\hline & & & & 202 & 1.6567 & 500 & 2.0569 \\
\hline & & & \multirow{5}{*}{3} & 284 & 1.7263 & 386 & 1.8824 \\
\hline & & & & 327 & 1.7423 & 725 & 1.5 \\
\hline & & & & 490 & 1.2279 & 407 & 1.8224 \\
\hline & & & & 324 & 1.3962 & 536 & 1.8492 \\
\hline & & & & 381 & 1.3173 & 374 & 2.0091 \\
\hline & & \multirow{15}{*}{3} & \multirow{5}{*}{1} & 74 & 6.4062 & 1033 & 1.1621 \\
\hline & & & & 68 & 6.5 & 874 & 1.1031 \\
\hline & & & & 74 & 7.3529 & 1439 & 0.989 \\
\hline & & & & 115 & 5.8776 & 1332 & 0.9358 \\
\hline & & & & 95 & 7.1667 & 940 & 1.0765 \\
\hline & & & \multirow{5}{*}{2} & 68 & 7.2069 & 1024 & 1.1542 \\
\hline & & & & 93 & 6.9474 & 998 & 1.3955 \\
\hline & & & & 137 & 4.807 & 779 & 1.6479 \\
\hline & & & & 220 & 4.7159 & 365 & 2.0194 \\
\hline & & & & 200 & 4.4079 & 902 & 1.5524 \\
\hline & & & \multirow{5}{*}{3} & 327 & 2.6471 & 353 & 2.1013 \\
\hline & & & & 97 & 5.4 & 249 & 1.8776 \\
\hline & & & & 330 & 2.5526 & 226 & 1.6415 \\
\hline & & & & 151 & 4.08 & 191 & 1.5 \\
\hline & & & & 251 & 2.4889 & 321 & 1.4267 \\
\hline
\end{tabular}




\begin{tabular}{|c|c|c|c|c|c|}
\hline & & & & Uncon & trated \\
\hline Species & $\begin{array}{c}10^{\mathrm{x}} \\
\mathrm{CFU} / \mathrm{ml}\end{array}$ & $\begin{array}{l}\text { Biological } \\
\text { replicate }\end{array}$ & $\begin{array}{l}\text { Technical } \\
\text { replicate }\end{array}$ & Total Cluster Size & $\begin{array}{l}\text { Bead-to-cluster } \\
\text { Ratio }\end{array}$ \\
\hline \multirow{45}{*}{ E.coli } & \multirow{45}{*}{8} & \multirow{15}{*}{1} & \multirow{5}{*}{1} & 292 & 1.2568 \\
\hline & & & & 404 & 0.6304 \\
\hline & & & & 587 & 0.6981 \\
\hline & & & & 402 & 0.7358 \\
\hline & & & & 642 & 0.5082 \\
\hline & & & \multirow{5}{*}{2} & 305 & 1.322 \\
\hline & & & & 311 & 1.2577 \\
\hline & & & & 396 & 0.9431 \\
\hline & & & & 342 & 0.8702 \\
\hline & & & & 251 & 0.6667 \\
\hline & & & \multirow{5}{*}{3} & 191 & 1.76 \\
\hline & & & & 284 & 1.0208 \\
\hline & & & & 499 & 0.9744 \\
\hline & & & & 493 & 0.908 \\
\hline & & & & 259 & 1.0282 \\
\hline & & \multirow{15}{*}{2} & \multirow{5}{*}{1} & 280 & 1.2568 \\
\hline & & & & 390 & 0.6304 \\
\hline & & & & 439 & 0.6981 \\
\hline & & & & 402 & 0.7358 \\
\hline & & & & 496 & 0.5082 \\
\hline & & & \multirow{5}{*}{2} & 265 & 1.322 \\
\hline & & & & 397 & 1.2577 \\
\hline & & & & 481 & 0.9431 \\
\hline & & & & 595 & 0.8702 \\
\hline & & & & 449 & 0.6667 \\
\hline & & & \multirow{5}{*}{3} & 208 & 1.76 \\
\hline & & & & 332 & 1.0208 \\
\hline & & & & 297 & 0.9744 \\
\hline & & & & 341 & 0.908 \\
\hline & & & & 258 & 1.0282 \\
\hline & & \multirow{15}{*}{3} & \multirow{5}{*}{1} & 225 & 2.6324 \\
\hline & & & & 269 & 2.2099 \\
\hline & & & & 207 & 2.85 \\
\hline & & & & 228 & 2.9464 \\
\hline & & & & 226 & 2.7971 \\
\hline & & & \multirow{5}{*}{2} & 365 & 0.8495 \\
\hline & & & & 458 & 0.7297 \\
\hline & & & & 238 & 0.6154 \\
\hline & & & & 392 & 0.55 \\
\hline & & & & 448 & 0.7373 \\
\hline & & & \multirow{5}{*}{3} & 239 & 1.4127 \\
\hline & & & & 400 & 0.7333 \\
\hline & & & & 341 & 0.6333 \\
\hline & & & & 371 & 0.4804 \\
\hline & & & & 427 & 0.5446 \\
\hline
\end{tabular}

